EDUKACJA MIĘDZYKULTUROWA

2013, nr 2

ISSN 2299-4106

\title{
Adela KoŻyCZKOWSKA
}

\section{„Młodokaszubi” - fenomen kulturowy. Przyczynek do namysłu nad edukacją regionalną ${ }^{1}$}

Streszczenie: W opracowaniu podjęto próbę rozpoznania - czym w swej istocie był fenomen kulturowy „Młodokaszubi” i jakie wywarł on konsekwencje dla kształtowania kaszubskiej idei regionalizmu oraz w jaki sposób może wzbogacać myślenie o edukacji regionalnej w ogóle. Autorka formułuje tezę, zgodnie z którą myśl młodokaszubska stanowi punkt węzłowy etnicznej biografii Kaszubów - jest bowiem wyrazem kulturowego rozwoju idei regionalizmu kaszubskiego. Potwierdza zarazem Herderowską tezę, że każde jestestwo posiada własny świat, i to wewnątrz tego świata wytworzony powinien być typowy dla niego wzorzec. Regionalizm i edukacja regionalna są nierozerwalnie związane z pedagogicznością i politycznością kulturowego bycia człowieka w świecie.

Słowa kluczowe: kultura, kultura regionalna, edukacja regionalna, edukacja międzykulturowa, „Młodokaszubi”

\section{Wprowadzenie}

Młodokaszubi stworzyli fenomen nie tylko w obrębie kultury kaszubskiej, ale także w przestrzeni kultur regionalnych oraz w przestrzeni regionalnego myślenia o kulturze w ogóle. Trudno odnaleźć w polskich regionach podobny potencjał, oczywiście można go bez trudu dostrzec w ogólnych dziejach rozwoju idei, pod postacią „Młodej Polski”, ale przecież tego typu nurty dotykały dużych, a nie małych narodów (szczepów) żyjących w rozmaitych relacjach $\mathrm{z}$ dużymi narodami. Dodatkowej szczególności nadaje tu fakt, że jakkolwiek młodokaszubskość niejako „narodziła się” na Kaszubach, to równocześnie „narodziła się" w Polsce, która geograficznie i politycznie nie istniała.

Wyjątkowość Młodokaszubów polegała też na tym, że udało im się „być razem" i przekonać do swej idei innych - choć niewielu - Kaszubów. Po-

1 Prezentowany tekst stanowi roboczy fragment książki: Fenomeny kultury kaszubskiej. Studium edukacji regionalnej (także roboczy tytuł projektu). 
winnam napisać: „Kaszubów - Polaków” - bo tak pewnie chciałby Jan Karnowski. W obrębie młodokaszubskości wypracowano nie tylko ideologię, ale także program (doktrynę), który zaczęto wcielać w życie, a podstawą obu było uznanie polityczności i pedagogiczności kultury, w tym kulturowych działań edukacyjnych.

Celem tego tekstu jest próba rozpoznania, czym w swej istocie był ów fenomen i jakie wywarł on konsekwencje dla kształtowania kaszubskiej idei regionalizmu, i w jaki sposób może on wzbogacać myślenie o edukacji regionalnej w ogóle.

\section{Kontekst teoretyczny problemu: kultura}

Dla Młodokaszubów kultura miała wymiar polityczny. Może się to wydawać oczywiste z racji momentu historycznego i geograficznego, w którym powstał nurt. Wydaje się jednak, że Młodokaszubom szło nie tylko o przeciwdziałanie konsekwencjom rygorystycznej polityki germanizacyjnej wobec Kaszubów: ta była pojmowania jako polityka kulturowa ${ }^{2}$. Choć można by sądzić, że szło o doraźne działania, to analiza prac Młodokaszubów wskazuje, że stawką w podjętych działaniach było zachowanie i rozwijanie materialnej oraz niematerialnej kultury kaszubskiej, a także o podniesienie poziomu skolaryzacji ludności kaszubskiej w obrębie: 1) edukacji języka i kultury kaszubskiej, 2) edukacji języka i kultury polskiej, 3) edukacji - językowej i zawodowej w kulturze dominującej (niemieckiej). W tym ostatnim przypadku postulowano, by przygotować dzieci - jako przyszłych dorosłych do uczestnictwa w wytwarzaniu oraz konsumpcji dóbr ekonomicznych. Zaryzykuję twierdzenie, że elementem łączącym owe postulaty było nie tyle obudzenie czy też pogłębianie świadomości własnej kultury kaszubskiej, ale budzenie świadomości własnej polityczności i konieczności uczestnictwa w życiu politycznym państwa: choćby w takich przejawach jak znajomość prawa wyborczego i jego realizacja, w procesie wybierania przedstawicieli do parlamentu w zgodzie z potrzebami/interesami wszystkich Kaszubów, a nie na zasadzie czczych obietnic osób, którym na sercu nie leżał interes Kaszubów.

2 Takie stanowisko nie było obce i innym narodom słowiańskim znajdującym się w niewoli germańskiej, rosyjskiej, austriackiej, węgierskiej, tureckiej. Zresztą sam słowianofilizm i panslawizm stanowią odpowiedź na kulturowe zagrożenie, którego narody słowiańskie doświadczały już od przełomu XIV/XV wieku do początków XX wieku. 
Młodokaszubów wyróżniało uznanie, że kultura osiąga nade wszystko wymiary polityczne. Pojawia się tu także myślenie o kulturze jako edukacji (wychowanie, kształcenie), antropologii oraz ekonomii (w sensie gospodarowania). Rdzeniem programu Młodokaszubów było całościowe ujmowanie kultury jako szeregu splecionych ze sobą procesów o charakterze politycznym, edukacyjnym, antropologicznym, geograficznym, historycznym, ekonomicznym itp. Procesy te okazały się dla siebie wzajemnie tożsame pod względem przyczyn i skutków ${ }^{3}$.

Młodokaszubi sięgają do dorobku Floriana Ceynowy, ten zaś swój program społeczno-edukacyjny i językowy w zakresie kultury i języka kaszubskiego zbudował na programie słowianofilów austriackich, a właściwie słowackich (jeśli wziąć pod uwagę przynależność narodową): Jana Kollára i Pavla Josefa Šafári$\mathrm{ka}^{4}$. Ci natomiast pozostawali pod dużym wpływem filozofii Johanna Gottfrieda Herdera, szczególnie jest to widoczne w myśli Kollára, który bezpośrednio przejmuje Herderowskie kategorie i tezy, które rozwija, i dzięki nim tworzy dość spójny program (doktrynę) panslawistyczny. Trudno współcześnie orzec, czy sympatia Słowian dla Herdera płynęła z tego, że stworzył on całościową, uniwersalną koncepcję kultury, jako całości wewnętrznie zróżnicowanej, czy też dlatego zwrócił na siebie uwagę, że uznał lud słowiański za przykład wzorcowy $^{5}$, jeśli idzie o potencjał wyjściowy do konstruowaniu relacji między kulturami. Pozostawiam jednak rozwiązanie tego dylematu poza tekstem.

Wracając do głównego wątku pracy: warto poczynić dwie uwagi. Pierwsza dotyczy odkrycia natury wielokulturowości świata przez Herdera; druga wiąże się z metodologicznym zabiegiem, jakiego z konieczności dokonali Kollár i Šafarik ${ }^{6}$ (szczególnie Kollár), aby zmienić to, co filozoficzne i pedagogiczne

3 Całościowe ujęcie kultury jest typowe nie tylko dla Młodokaszubów, ale jest obecne w programach społeczno-politycznych dziewiętnastowiecznych badaczy kultur słowiańskich.

4 Z powodu ograniczeń związanych z formułą opracowania, odwołam się jedynie do myśli Jana Kollára, która - w moim rozumieniu - stanowi kontynuację myśli Johanna Gottfrieda Herdera.

5 J. G. Herder: Narody stowiańskie. W: J. G. Herder: Pomysty do filozofii dziejów rodzaju ludzkiego. T. 3. Wilno 1838, Nakład i druk: T. Glücksberga, s. 131-134.

6 T. Labus: Recepcja pogladów Herdera w Europie Wschodniej i Południowo-Wschodniej. „Studia Filozoficzne” 1986, nr 7 (248); R. Dupkala: „Filozofia humanitaryzmu" Herdera i jej oddźwięk na Stowacji w twórczości J. Kollara i P. J. Šafarika. W: M. Heinz, M. Potępa, Z. Zwoliński (red.): Rozum i świat. Herder i filozofia XVIII, XIX i XX wieku. Warszawa 2004, Wydawnictwo Genesais. 
w myśleniu Herdera, w to, co polityczne i edukacyjne w programie słowianofilów austriackich, a co pozwoliło Ceynowie stworzyć program społeczno-kulturowy i polityczny. Wszystko to razem poważnie zasiliło myślenie Młodokaszubów. Do wątku tego wrócę w ostatniej części pracy.

\subsection{Herderowska koncepcja kultury jako wewnętrznie zróżnicowanej całości}

Herder rozpoczyna swój namysł nad kulturą od jej badania - a właściwie przeżycia hermetycznego niezadowolenia ze swego stanu wiedzy oraz dostępnych metodologii. „Wczesna wiedza” Herdera o kulturze ukształtowana została przez oświeceniowe pojmowanie jedności i doskonałości człowieka oraz jego kultury ${ }^{7}$. Lecz Herder nie znalazł tu odpowiedzi na podstawowe, nurtujące go pytania: idzie w nich o szeroko rozumiane związki człowieka z człowiekiem oraz człowieka ze światem, a także o dzieło „rodu ludzkiego”, „ducha”, „kulturę świata”, jako kulturę wszystkich ziem, czasów, ludów, nurtów, form. Idzie o różnorodność nie tylko natury i kultury, ale o różnorodność w obrębie samej kultury, którą pojmował jako całość/jedność ${ }^{8}$; oraz o mieszaninę owej różnorodności, w tym, co całościowe ${ }^{9}$. Herder chciał poznać to, co wspólne i scalające w rozwoju ludzkim: chciał poznać jego regułę (regularnośćs ${ }^{10}$.

7 W. Hinrichs: Do realiów! Nowoczesne boje o „wyższe stanowisko”. Herder jako prekursor indywidualistycznej filozofii i pedagogiki, jak również filozofii i pedagogiki kultury. W: M. Heinz, M. Potępa, Z. Zwoliński (red.): Rozum i świat. Herder i filozofia XVIII, XIX i XX wieku. cyt. wyd., s. 170.

8 J. G. Herder: Pomysty do filozofii dziejów rodzaju ludzkiego. T. 1. Wilno 1838, Nakład i druk: T. Glücksberga, s. 94 i n., 2 i n.

9 J. G. Herder: Dziennik z mojej podróży z roku 1769. Olsztyn 2002, Wydawnictwo Wspólnoty Kulturowej „Borussia”, s. 15.

10 Zwrot poznawczy, jakiego doświadczył Herder i związana z tym silnie odczuwana potrzeba „samodzielnego zobaczenia/poznania” dostarczyły myślicielowi materiału empirycznego dla dociekań filozoficznych i edukacyjnych. Herder w toku swej biografii „posiadł coś”, co można by nazwać „marzeniem poznawczym”: pragnął odkryć zamysł kierujący światem. W swych studiach postawił pytanie o to, ,jak to zrobić". Pisze: Jak (?) mając głowę „pełną pewnych czasów, które są miłe”, ale i „odciągają wzrok”, jak „[...] ogarnąć całość zmieniających się czasów, uporządkować je, subtelnie śledzić, wyróżnić tylko to, co najważniejsze w każdej scenie, spokojnie przyglądać się zmianom” „I wszystko to nazwać!”. J. G. Herder: Jeszcze jedna filozofia historii kształto- 
Herder rozpoczyna badanie kultury (cywilizacji) od badania świata natury (przyrody) i na tym polu stara się rozpoznać prawidłowości, które są nie tyle efektem boskiego stworzenia świata, ale przede wszystkim uczenia się świata przez organizmy żywe (tzw. jestestwa). Autor wysuwa w tym obszarze dociekań ważką tezę dla późniejszego myślenia o kulturze: każde stworzenie (jestestwo) posiada własny (właściwy sobie) świat ${ }^{11}$.

Kultura - jako konsekwencja oświecania, rozumianego właśnie jako bycie poddawanym procesom „ukulturowienia” za pomocą metod wychowawczych $^{12}$ - jest właściwością ludzką. Człowiek staje się jej uczestnikiem dzięki wychowaniu „[...] przez naśladowanie i wprawę, a zatem przez przejście oryginału w kopię [...]"13; wychowanie człowieka stwarza możliwość powtórnych narodzin i nadaje ciągłość jego życiu. Poniekąd włącza go w całość wychowania rodu ludzkiego i w ten sposób stwarza kulturową całość/jedność świata ${ }^{14}$.

Warto wyakcentować, że Herder odchodzi w swej myśli od oświeceniowego modelu kultury ${ }^{15}$. I warto też wspomnieć, że słowo „kultura” pojawiło się w języku warstw wykształconych dopiero w XVII wieku ${ }^{16}$, a w jego końcu kategoria „kultura” zaczęła być używana samodzielnie i oznaczała „kształ-

wania się ludzkości. W: T. Naumowicz (wybór i opr.): Państwo a społeczeństwo. Wizje wspólnot niemieckich od oświecenia do okresu restauracji. Poznań 2001, Wydawnictwo Poznańskie, s. 251, 244. Por. J. G. Herder: Wyjątki z listów o Osjanie i pieśniach dawnych ludów. W: J. G. Herder: Wybór pism. Wrocław - Warszawa - Kraków - Gdańsk - Łódź 1987, Zakład Narodowy Imienia Ossolińskich, s. 209.

11 J. G. Herder: Pomysty do filozofii dziejów rodzaju ludzkiego. T. 1. cyt. wyd., s 71; tenże: Pomysty do filozofii dziejów rodzaju ludzkiego. T. 2. Wilno 1838, Nakład i druk: T. Glücksberga, s. 61-63, 91, 116-117.

12 Z. Bauman: Prawodawcy i ttumacze. Warszawa 1998, IFiS PAN, s. 118, 120.

13 J.G. Herder: Pomysty do filozofii dziejów rodzaju ludzkiego. T. 2. cyt. wyd., s. 91.

14 Tamże, s. 89-90.

15 Jednym z elementów oświeceniowego pojmowania kultury było przeświadczenie o jej jednorodności. Trzeba też przypomnieć, że kultura oświeceniowa wiązała się z warstwami wyższymi, wykształconymi. Lud przecież pojmowany jako „najgłupszy i najwystępniejszy z ludzi” (Diderot), lud nie istniał samoistnie, bez dostępu do praw, zajmował miejsce między człowiekiem a zwierzęciem (Wolter). Lud był więc jakimś stadium pośrednim, można go było co prawda poddać procesom cywilizacyjnym, ale: sens oświecenia sprowadzał się nie tyle do „oświecania”, ale do pomocy władzy w utrzymywaniu dotychczasowej struktury społecznej. Za: Z. Bauman: Prawodawcy i ttumacze. cyt. wyd., s. 87-103.

16 Z. Bauman: Prawodawcy i ttumacze. cyt. wyd., s. 104. 
towanie ducha”. Do połowy XVIII wieku - „kulturę” rozumiano statycznie, jako opis wytworu działań edukacyjnych, a więc wzorców dla ludzi „robionych" przez edukację. Sam proces dziania się kultury był tu pomijany. Kultura rozumiana była jako jedność, uniwersum - jako unitarny ideał stosowany do człowieka, który stał ponad narodami i społecznościami. Tak rozumiana kultura cechowała się: 1 ) optymizmem (wiarą w nieskrępowaną elastyczność ludzkich cech), 2) uniwersalizmem (jeden model kultury, który znajduje zastosowanie do każdej zbiorowości, czasu i miejsca), 3) etnocentryzmem a właściwie europocentryzmem (wiarą, że osiemnastowieczny model kultury europejskiej jest szczytowym osiągnięciem ludzkości, zaś wszystkie inne narody świata będą musiały ją naśladować). Kultura zatem (podobnie jak cywilizacja jako edukacyjny proces inkulturacji innych i odmiennych) nabrała znaczenia politycznego: stała się niczym innym jak polityką kulturową ${ }^{17}$.

Różnica związana z rasą czy zwyczajami była dostrzegana, ale pojmowano ją raczej jako naturalną konsekwencję boskiego kreacjonizmu i uznawano, że nie zasługuje ona na to, by ją „badać” czy się nią w inny sposób zajmować ${ }^{18}$. Tak długo zatem, jak długo różnica nie była wiązana z kulturą (czy cywilizacją w rozumieniu edukacyjnym) tak długo nie przeszkadzała ludziom w ich wzajemnych relacjach. Oczywistym jest, że ludzie wcześniej posiadali kulturę, natomiast nie byli świadomi jej politycznego i edukacyjnego znaczenia. Ów moment „odkrycia” kultury uświadomił człowiekowi istnienie zbiorowości politycznych, które posiadają kulturę (cywilizację), i tych, które owej kultury (cywilizacji) nie posiadają. Przy czym podział ten budowany był na selekcji negatywnej i wiązał się z przyjęciem uniwersalistycznego i europocentrycznego wzorca kulturowego (w zasadzie rzymsko-germańskiego, na co zwraca uwagę $\operatorname{Herder}^{19}$ ). Narody, które zorganizowane były na przyjętej normie kulturowej i politycznej, uznano za ucywilizowane; te, które zorganizowane były na innym modelu, uznano za barbarzyńskie, wymagające „wyplenienia” wewnętrznego patologicznego wzorca i zastąpienia go poprawnym. W XVIII wieku człowiek w pełni uzmysłowił sobie obecność różnicy kulturowej. Zaś na przełomie XVIII i XIX wieku zaczęła pojawić się świadomość lokalności kultury (w dzisiejszym rozumieniu) oraz świadomość jej wielości (także

17 Ph. Bénéton: Histoire de mots: culture as civilization. Paris 1975, Presses de la foundation nationale des sciences politiques, s. 23 i n. Za: Z. Bauman: Prawodawcy i ttumacze. cyt. wyd., s. 122.

18 Z. Bauman: Prawodawcy i ttumacze. cyt. wyd., s. 105.

19 Patrz przypis nr 32. 
w dzisiejszym rozumieniu), przy czym lokalność i wielość przestały być wiązane z geograficznymi i administracyjnymi granicami państwa.

Poszukiwania metodologiczne i podjęcie studiów nad kulturą narodów w optyce zakwestionowania oświeceniowego modelu kultury doprowadziły Herdera do sformułowania jednej z najistotniejszych tez w dziejach ludzkości: uznał on, że świat jest kulturą, i świat jako kultura tworzy wewnętrznie zróżnicowaną całość ${ }^{20}$. Kultura nie jest dziełem natury, ale jest wytworem ludzkim. Choć jej naturalne podstawy wytworzyły się w toku ewolucji organizmów, czyli ich uczenia się (przystosowania) istniejących warunków klimatycznych i geograficznych, to sama kultura powstała w procesie ewolucyjnych zmian społecznych ${ }^{21}$. O ile świat jest dla Herdera kulturą, o tyle jego immanentną cechą jest pedagogiczność (w sensie namysłu nad edukacyjnymi aspektami rozwoju człowieka) i edukacyjność (w sensie konkretnego działania). Kultura stanowi uniwersum, osiągnięte dzięki praktykom edukacyjnym, ale wewnątrz tego uniwersum znajdują się partykularne kultury narodów/ plemion nieeuropejskich. Wynika stąd istotna dla Herderowskiej filozofii kultury zasada: świat nie dzieli się na kultury gorsze i lepsze. Przecież tzw. ludy barbarzyńskie (nie-cywilizowane) również wytwarzają właściwe sobie kultury. „Całość” oznacza nic więcej, jak „całościową jedność” świata ${ }^{22}$ i to w tej całości pojawiają się różnice właściwe ludziom i narodom. Edukacyjność świata wiąże się ze zmianą społeczną i kulturową, a więc z koniecznością uczenia (się), ale też w wyniku procesów edukacyjnych tworzą się nowe jakości kulturowe. Edukacja związana jest z adaptacyjnymi - i pośrednio emancypacyjnymi - zdolnościami człowieka ${ }^{23}$.

Sam zaś człowiek jest „wytworem” kultury ${ }^{24}$, i równocześnie kultura mogła się „wytworzyć” tylko dzięki temu, że człowiek działał z człowiekiem,

20 J. G. Herder: Jeszcze jedna filozofia historii kształtowania się ludzkości. cyt. wyd., s. 251, 253, 258-259, 261 i n.

21 Warto zauważyć, że Herder buduje teorię ewolucji naturalnej (biologicznej) i teorię ewolucji społecznej (kulturowej). Pierwsza warunkuje drugą, ale druga uzdatnia dla człowieka pierwszą. Szczególnie jest to widoczne w Pomysłach do filozofii dziejów rodzaju ludzkiego oraz Dziennikach z mojej podróży z roku 1769.

22 J. G. Herder: Jeszcze jedna filozofia historii kształtowania się ludzkości. cyt. wyd., s. 251, 253, 258-259, 261 i n.

23 Tamże. J. G. Herder: Wyjątki z listów o Osjanie i pieśniach dawnych ludów. cyt. wyd., s. 212, 227, 234, 236.

24 J. G. Herder: Jeszcze jedna filozofia historii kształtowania się ludzkości. cyt. wyd., s. 243; tenże: Wyjątki z listów o Osjanie i pieśniach dawnych ludów. cyt. wyd., s. 188-189. 
dla człowieka. Aby jednak kultura była w ogóle możliwa, koniecznym jest "stworzenie" społecznego wymiaru życia człowieka. Ale też: człowiek staje się człowiekiem i może żyć życiem ludzkim tylko dzięki wychowaniu, które musi dostać od innych ludzi ${ }^{25}$. W sensie edukacyjnym - człowieczy los wpisany jest w dzieje rozwoju świata, w taki sposób, że nie ma w nim dwóch identycznych biografii. W obrębie kultury istnieje jednak spór o charakter „wytworów”, bo tym, co różni ludzi - podobnie jak narody - jest jedynie treściowe wypełnienie kultury, która ich kształtuje ${ }^{26}$. Dla Herdera człowiek może być człowiekiem epoki bądź człowiekiem kultury. W pierwszym przypadku zamyka on w sobie treści danego miejsca i czasu ${ }^{27}$, w drugim niesie w sobie spuściznę minionych epok ${ }^{28}$. Człowiek kultury i narody kultury uczą się i kształtują w postępie dziejów oraz w zmaganiu z teraźniejszością. Tym, co również treściowo różnicuje kulturę człowieka oraz narodu, są: czas, miejsce, klimat, potrzeba, świat ${ }^{29}$.

Herder dochodzi do wniosku, że nie istnieje wzorzec kultury idealnej, który mógłby być uniwersalny dla kultur wszystkich narodów. Każdy naród sam dla siebie wytwarza wzorzec, który zamyka w sobie także walory edukacyjne ${ }^{30}$. To w tym właśnie sensie każde jestestwo wytwarza właściwy sobie świat ${ }^{31}$. Herder postrzega tzw. kultury barbarzyńskie jako te, które posiadają własne wzorce: są one „normalne” i wewnętrznie właściwe każdej kulturze. Herder nie dokonuje kulturowych porównań typu: normalne - nie-

25 J. G. Herder: Pomysty do filozofii dziejów rodzaju ludzkiego. T. 2. cyt. wyd., s. 88-89, 92. Herder pisze: „[...] każdy człowiek staje się człowiekiem tylko przez wychowanie [...]. [...] Bo nikt z nas przez samego siebie człowiekiem nie został. Cały twór w nim ludzkości łączy się ściśle przez urodzenie umysłowe, wychowanie, z jego rodzicami, nauczycielami, przyjaciółmi, ze wszystkimi okolicznościami w biegu jego życia, a zatem z jego ludem i przodkami, [...] z całym łańcuchem rodzaju, który w jakim bądź ogniwie zetknął się z jaką władzą jego duszy”. Za: J. G. Herder: Pomysty do filozofii dziejów rodzaju ludzkiego. T. 2. cyt. wyd., s. 89-90.

26 Patrz przykładowo: J. G. Herder: Pomysty do filozofii dziejów rodzaju ludzkiego. T. 2. cyt. wyd., s. 59.

27 J. G. Herder: Jeszcze jedna filozofia historii kształtowania się ludzkości. cyt. wyd., s. 256.

28 Tamże, s. 242-243 i n.

29 Tamże, s. 244-245.

30 Tamże, s. 249, 264. J.G. Herder: Wyjątki z listów o Osjanie i pieśniach dawnych ludów. cyt. wyd., s. 188-189.

31 J. G. Herder: Pomysty do filozofii dziejów rodzaju ludzkiego. T. 1. cyt. wyd., s. 71. 
-normalne/patologiczne. I nie odnosi europejskości ${ }^{32}$ jako wzorca normalności do tych wszystkich kultur, które konstruowane były na wzorcach odmiennych. Raczej dostrzega pewną nieadekwatność wiedzy, której używano do badania czy poznania i związaną z tym intelektualną nieudolność w tworzeniu opisów innych kultur a także „ślepotę” na całościowe ujmowanie zjawisk kulturowych ${ }^{33}$.

Artykułowana przez Herdera potrzeba stworzenia kulturowej idei świata przyczyniła się do zrekonstruowania całościowego modelu kultury jako świata, w którym narody żyły na zasadach: a) wzajemności, b) istnienia obok siebie, c) braku zgody zagarniania siłą (niewolenia). Myśl Herdera została w szczególny sposób podjęta i rozwinięta przez Kollára. Podstawą całościowego modelu kultury jest językowy obraz świata.

\subsection{Herdera i Kollára językowa koncepcja kultury}

Język/mowa jest dla Herdera działaniem ${ }^{34}$ i najważniejszym elementem kultury duchowej każdego narodu. Lud staje się "ludem” w sensie narodu wtedy, gdy będzie posiadał swe „ukształcenie narodowe”, czyli język ${ }^{35}$. W języku

32 Herder zauważa, że tzw. wzorzec europejskości jest w zasadzie zbieżny z modelem kultury germańsko-rzymskiej. Jest to jednak partykularna część kultury europejskiej, ale jako partykularna część przyjęła ona na siebie zadanie reprezentowania całości europejskiej kulturowości, jako szczególna forma sprzeciwu wobec obecności w świecie innych modeli kulturowych. Jednocześnie ujawnia się tu również zasada przygodności, kiedy to porządek uniwersum budowany jest na logice reprezentacji całości przez ekwiwalenty i dyferencyjny element w drodze przypadkowości. Patrz: E. Laclau: Emancypacje. Wrocław 2004, Wydawnictwo Naukowe Dolnośląskiej Szkoły Wyższej Edukacji TWP.

33 J. G. Herder: Pomysty do filozofii dziejów rodzaju ludzkiego. T. 2. cyt. wyd., s. 35; tenże: Jeszcze jedna filozofia historii kształtowania się ludzkości. cyt. wyd., s. 266; tenże: Wyjątki z listów o Osjanie i pieśniach dawnych ludów. cyt. wyd., s. 183, 196-197, 222. Stanowisko to w przyszłości znajdzie odbicie w myśli Ruth Benedict. Antropolożka stworzyła nurt antropologii kulturowej, w której za podstawową przyjęła zasadę normalności badanych kultur. Posunęła się nawet dalej w swej pracy, zakładała bowiem swoistą niekompletność własnej kultury, co w szczególny sposób zmuszało ją do poszukiwania „narzędzi badania i opisu”, które nie zniekształcałby badanej kultury i jednocześnie pozwalałyby całościowo ujmować badane światy.

34 J. G. Herder: Wyjątki z listów o Osjanie i pieśniach dawnych ludów. cyt. wyd., s. 199.

35 J. G. Herder: Pomysty do filozofii dziejów rodzaju ludzkiego. T. 2. cyt. wyd., s. 5. 
narody wypowiadają siebie ${ }^{36}$, język oddaje stan wiedzy danego narodu oraz jego charakter ${ }^{37}$, a także poziom jego rozwoju, który można rozpoznać po dojrzałości (normatywności ${ }^{38}$ - uzupełnienie A.K.) i abstrakcyjności ${ }^{39}$ języ$\mathrm{ka}^{40}$. Język jako mowa jest też środkiem wychowawczym, a język jako pismo ${ }^{41}$ - środkiem naukowym ${ }^{42}$.

Język jako mowa nabiera charakteru politycznego w tym sensie, że stwarza narodowi możliwość przetrwania: to tu mają szanse przetrwać zmysłowość, kulturowa czystość i tradycja ojców - nawet wtedy, gdy wiedza ta przekazywana jest jedynie w formie ustnej, w postaci pieśni wypowiadanych przez prosty i niewykształcony lud. W Herderowskiej filozofii języka słowo wydaje się wypowiadane nie dla czystego faktu artykułowania, ale dla treści, które pobudzać mają ducha, który gotów będzie stawić opór czasowi przez afiliowanie w życie i wynikanie z życia. Idzie zatem o identyfikację słowa i życia: tożsamość słowa i doświadczenia społecznego, historycznego i kulturowego człowieka oraz narodu ${ }^{43}$. Pismo - jako „martwe litery” - nie ma w sobie zamkniętej mocy słowa wypowiadanego ${ }^{44}$, czyli mocy mówienia. Pismo jest zaledwie cieniem słowa i tylko praktyka używania czyni je praktycznym i jednoznacznym, ale to mowa/słowo ${ }^{45}$ jest napełnione duchem kultury ${ }^{46}$, i nie można jej całko-

36 Tamże, s. 75, 99.

37 Tamże, s. 105 i n.

38 J. G. Herder: Rozprawa o pochodzeniu jezzka. W: J. G. Herder: Wybór pism. Wrocław - Warszawa - Kraków - Gdańsk - Łódź 1987, Zakład Narodowy imienia Ossolińskich, s. 127-133. Herder gramatykę nazywa filozofią o języku.

39 J. G. Herder: Rozprawa o pochodzeniu jezyka. cyt. wyd., s. 123-127.

40 J. G. Herder: Pomysty do filozofii dziejów rodzaju ludzkiego. T. 2. cyt. wyd., s. 107, tenże: Rozprawa o pochodzeniu jezzka. cyt. wyd., s. 136.

41 Herder uznaje pismo za najtrwalsze, najspokojniejsze i najskuteczniejsze narzędzie „[...] przez co działają narody na narody, wieki na wieki, i może się z czasem cały rodzaj ludzki zbieży u jednego łańcucha podania braterskiego". Za: J. G. Herder: Pomysty do filozofii dziejów rodzaju ludzkiego. T. 2. cyt. wyd., s. 107-108.

42 J. G. Herder: Pomysty do filozofii dziejów rodzaju ludzkiego. T. 2. cyt. wyd., s. $107,111-112$.

43 J. G. Herder: Wyjątki z listów o Osjanie i pieśniach dawnych ludów. cyt. wyd., s. 178, 184, 187, 188-189, 191, 206, 211, 223.

44 Tamże, s. 183; tenże: Rozprawa o pochodzeniu języka. cyt. wyd., s. 67.

45 Herder pisze wprost o pieśni ludu.

46 J. G. Herder: Wyjątki z listów o Osjanie i pieśniach dawnych ludów. cyt. wyd., s. 206, 211. 
wicie sprowadzić do „liter”47, gdyż to mowa posiada moc edukacyjną dzięki zawartemu w niej i ujawnianemu przez nią doświadczeniu. Słowo wypowiadane w teraźniejszości odnosi się bowiem do tego, co zrodzone, pomyślane, wymyślone w przeszłości i tylko w momencie wypowiadania ujawniane jest $\mathrm{z}$ uniesieniem i żarem. Mowa wiązana jest zawsze $\mathrm{z}$ kontekstem wypowiadania, bezpośredniością dziania się i z emocjami ${ }^{48}$. To w tym właśnie rozumieniu zabrać narodowi język - możliwość mówienia - znaczy pozbawić naród kultury, bo to język jest tym, co każdy naród ma najcenniejszego. Naród bowiem żyje w języku, a odebrać bądź wzgardzić językiem, to pozbawić naród dziedzictwa. Pozbawić naród języka - podobnie jak pozbawić człowieka języka - oznacza odebrać mu rozum, gdyż to właśnie język jest dowodem rozumowego ${ }^{49} \mathrm{i}$ refleksyjnego ${ }^{50}$ istnienia człowieka w świecie ${ }^{51}$. Co więcej: język - podobnie jak działanie - zaświadcza o życiu, i jego zmysłowości ${ }^{52}$. A ludzie, którzy mogą ze sobą rozmawiać, tworzą „królestwo ożywionych” i „działających” ${ }^{3}$.

Język jest właściwością ludzką - jest tworzony przez ludzi, dzięki temu że są ze sobą: „Język jest dla człowieka tak istotny, jak to, że jest on człowiekiem" ${ }^{54}$, ale też język jest kształtowany przez ludzi dla człowieka ${ }^{55}$. Mowa/słowo jako wymiar ludzkiego jestestwa staje się elementem tworzenia języka, polityki i kultury (sztuki) ${ }^{56}$. Przy czym to właśnie język jest „naturalnym organem rozumu” i „zmysłem ludzkiej duszy” i to właśnie język stwarza świat przez to, że go nazywa ${ }^{57}$ i tworzy społeczeństwo (naród/lud) ${ }^{58}$. W tym właśnie znaczeniu język jest naturalną zdolnością człowieka i tym, co odróżnia go od świata zwierząat ${ }^{59}$. Zaświadcza o jego niezależności i myśleniu (rozumie), dzięki

47 J. G. Herder: Rozprawa o pochodzeniu jezzyka. cyt. wyd., s. 65.

48 J. G. Herder: Wyjątki z listów o Osjanie i pieśniach dawnych ludów. cyt. wyd., S. 212.

49 J. G. Herder: Rozprawa o pochodzeniu języka. cyt. wyd., s. 83, s. 91-92, 97, 99.

50 Tamże, s. 87.

51 Tamże, s. 83.

52 Tamże, s. 102, s. 109, 111 i n.

53 Tamże, s. 103, 143.

54 Tamże, s. 81. Patrz także: s. 87, 89-90, 92.

55 Tamże, s. 140, 143.

56 Tamże, s. 97.

57 Tamże, s. 88, 92.

58 Tamże, s. 98.

59 Tamże, s. 133. 
językowi człowiek może działać z innymi w rozwadze i współ-tworzyć świat ${ }^{60}$ w taki sposób że zmysły pozostają w pewnej równowadze z rozumem ${ }^{61}$.

Herder zwraca uwagę na ważką zasadę czy też cechę związaną z tworzeniem języka przez ludzi: jest nią przypadkowość...

1. ...wiązania języka z geografią i czasem, a przede wszystkim ze społecznym kontekstem, w jaki tworzenie języka jest wikłane, oraz ze zmysłowością i intelektem ludzi, którzy w tym dziele uczestniczą ${ }^{62}$. Tworzenie języka wiązane jest więc z życiem ludzkim, tak by język tworzył coś dla żywego świata. A kiedy zamknięty zostaje w szkole i nie tworzy już dla żywego świata - zrywa z nim związki ${ }^{63}$ - zmienia się z tego, co nazwać można mową, w to, co nazywane jest pismem/literą, i co stanowi zaledwie cień słowa.

2. ...tworzenia duszy i sposobu myślenia ${ }^{64}$. A te są konsekwencją społecznego i kulturowego doświadczenia tak człowieka, jak i każdego narodu. Każdy człowiek i każdy naród posiadają wszelkie niezbędne zdolności do tego, by mógł się tworzyć język ${ }^{65}$. Każdy naród posiada język, który dostosowany jest do jego potrzeb: a stan potrzeb w pewnym sensie odzwierciedla poziom narodu. Żaden naród nie będzie się rozwijał, nie będzie pokonywał obszarów swej niewiedzy, nie będzie rozbudzał swych potrzeb i aspiracji, jeśli będzie żył w izolacji. I podobnie: żaden język nie będzie się dostatecznie dobrze tworzył, jeśli nie będzie wymiany doświadczenia między językami. Rozkwit narodów i tym samym rozwój języków jest możliwy wtedy, kiedy jeden naród przekaże swą tradycję i kulturę drugiemu. Wymiana - jak pisze Herder - jest najdoskonalszym czynnikiem rozwoju, jaki „wymyśliła” natura ${ }^{66}$. Zatem to, jaką duszę i jakie sposoby myślenia będzie wytwarzał język, jest powiązane z tym, jakie relacje naród (w tym język) będzie budował z innymi narodami (językami). Narody i ich języki mogą „żyć” na mocy wzajemności bądź mogą istnieć obok siebie we wzajemnym izolowaniu przy jednoczesnym braku zgody na zagarnianie siłą kultury narodu słabszego przez naród silniejszy.

\footnotetext{
60 Tamże, s. 134-135, 141, 143.

61 Tamże, s. 137, 138, 139.

62 Tamże, s. 145-146.

63 Tamże, s. 147.

64 Tamże, s. 150.

65 Tamże, s. 170.

66 Tamże, s. 170-171.
} 
3. ...tworzenia języka ojczystego/macierzystego, który jest dla dziecka światem pierwszym, jaki ono zobaczy, pierwszą emocją, jaką poczuje oraz pierwszą działalnością i radością, jaką się człowiek cieszy. To nic innego zatem jak „rodzinne tworzenie języka”, w kooperacji domu (rodziny) i tego, co na zewnątrz domu. Język tworzyć się może tylko dzięki związkom ze światem. To, jak tworzyć się będzie język ojczysty/macierzysty dziecka, jest dziełem natury i tego, że nieustannie musi ona konfrontować się z "chytrością polityka” i „mądrością filozofa”67. I choć cechą naturalną rozwoju języka jest przypadkowość, to kolejnymi ważnymi właściwościami są regularność i kształt języka - chodzi o gramatykę języka, która jest odzwierciedleniem „duszy ludzkiej” i „naturalnej logiki”"68. I dalej: choć rodzice nauczają swe dziecko języka, który jest już wykształcony, to zawsze jest on tylko w jakimś aspekcie/częściowo wykształcony i zawsze rozwija się on dalej, dzięki temu, że dzieci będą z konieczności go współtworzyć przez swą obecność w nowym, szerszym świecie. Rozwijanie języka wynika z naturalnej potrzeby człowieka i wynika z tego, że człowiek jest istotą posiadającą język, i to za pomocą mowy uobecnia się on w świecie ${ }^{69}$. Rozwój języka jest więc koniecznością, a jego przebieg warunkowany jest obecnością języka w doświadczania świata oraz w powiązaniu z edukacyjnymi aspektami ludzkiego rozwoju. Język - a właściwie jego rozwój - jest kulturowym świadectwem obecności.

4. ...języka, który staje się językiem plemienia ${ }^{70} ;$...bycia niczym, albo „królem”, w sensie „zgiń, albo stwórz sobie język”" Język jest konsekwencją, ale i czynnikiem zmieniającym przypadkowych ludzi w wewnętrznie powiązaną zbiorowość ${ }^{72}$. Język ewoluuje z języka ojczystego/rodzinnego w język ojczysty/plemienny ${ }^{73}$, ale to język rodzinny jest nieocenionym w swej wartości zasobem (skarbem) narodu (szczególnie małego) każdej części świata. Każdy naród - i ten wykształcony, i ten niewykształcony - w języku przechowuje wszystko to, co w nim

\footnotetext{
67 Tamże, s. 151.

68 Tamże, s. 153, 168-169, 170.

69 Tamże, s. 153-154.

70 Tamże, s. 151.

71 Tamże, s. 141.

72 Tamże, s. 148.

73 Tamże, s. 151.
} 
najcenniejsze: tradycję, mity, historię, poezję, mądrość, naukę, zabawę i taniec ${ }^{74}$. I tak jak rodzaj ludzki różni się wewnętrznie z tej przyczyny, że ludzie musieli uczyć się życia w odmiennych warunkach miejsca i czasu, tak nie mógł powstać jeden język narodowy. Dzieje się tak dlatego, że każdy naród wnosi do języka właściwe sobie doświadczenie społeczno-historyczne oraz właściwą sobie wymowę. Słowa - jak pisze Herder - posiadają właściwy językowi sens, który jest niczym innym jak nieskończonym polem rozmaitości, którego wyznacznikiem jest kultura połączona z geografią. W pewnym przecież sensie język jest tak samo powiązany z ziemią, jak i narodem, który tę ziemię zasiedla. I jakkolwiek języki różnią się - tak jak różnią się narody - to jest on naturalnym wytworem człowieka. Język wewnątrz rodziny i narodu jest tworzącą się jednością, choć języki narodów różnią się z tej przyczyny, że narody posiadają odmienne charaktery i przyzwyczajenia. Najistotniejszą jednak przyczyną różnienia się języków nawet bliskich sobie małych narodów jest ich sposób myślenia, życia oraz wzajemna nienawiść. Dlatego też jedność językowa jest dla Herdera niemożliwą do realizacji utopią, gdyż tworzyłaby ona unifikację kulturową, narody zaś potrzebują łączyć się w wewnętrznej jedności i uaktualniać w zewnętrznej różnorodności ${ }^{75}$.

Herder konstruuje językowy model świata, który buduje się na trzech zasadach: regularności, przygodności oraz wzajemności. Model ten opisuje świat jako kulturę, która jest wewnętrznie zróżnicowaną całością, co jest możliwe tylko dzięki regularności, przygodności i wzajemności. Jest to nie tylko model świata-kultury, ale podstawowa teza Herderowskiej filozofii kultury, która zawsze ma wymiar językowy (choć się obiektywizuje w postaci mowy/pisma i tego, co materialne) i zawsze stanowi wewnętrznie zróżnicowaną całość. Tym, co wyznacza charakter i stanowi możliwość zaistnienia, jest pedagogiczność (edukacyjność w sensie działania) oraz polityczność kultury: jednak i pedagogiczność, i polityczność nabierają u Herdera znaczenia językowego. Tym samym Herder tworzy klasyczną już dziś koncepcję uniwersum jako wewnętrznie zróżnicowanej całości, gdzie pedagogiczność i polityczność stanowią kulturowe wymiary bycia człowieka w świecie. W myśli Herdera uniwersum budowane jest $\mathrm{z}$ dyferencyjnych partykularyzmów,

\footnotetext{
74 Tamże, s. 155.

75 Tamże, s. 155-164, 169-170.
} 
a tym, co je łączy, jest ich ekwiwalentna i dodatnia zasada konsolidacyjna: przygodność, regularność i wzajemna konieczność rozwojowa ${ }^{76}$.

Herderowska koncepcja uniwersum znalazła swą kontynuację w myśli Kollára, który w rozprawie: O literackiej wzajemności między różnymi szczepami i narzeczami narodu stowiańskiego (Peszt 1837) ${ }^{77}$, stworzył myślowe podstawy panslawizmu austriackiego (wężej: czeskiego), który przyczynił się do wytworzenia ideologii tego ruchu, co w dalszej konsekwencji stanowiło zarzewie programu (doktryny) panslawistycznej, wokół której koncentrowały się debaty Pierwszego Zjazdu Słowiańskiego w Pradze w 1848 roku. Materialną jego reprezentację stanowił Manifest do Ludów Europy ${ }^{78}$.

Czynnikiem, który jednocześnie sprzyjał i przeszkadzał w rozwoju idei panslawizmu (i słowianofilstwa), była skomplikowana ówczesna sytuacja polityczna wielu narodów, które znalazły się w obcych kulturowo i politycznie formacjach państwowych. Stąd też - jak się wydaje - szczególny nacisk na polityczny wymiar kultury, a sytuacja zniewolenia wielu narodów przez te „wybrane", wiązana była z polityką kulturową, a szczególnym jej wymiarem była polityka językowa. Być może dlatego szczególna troska słowianofilów wiązała się ze stworzeniem takiej koncepcji narodu - a w zasadzie pan-narodu - która mogłaby przeciwstawić się politykom kulturowym takich narodów, jak Niemcy, Turcy czy Węgrzy. Szło więc o stworzenie pansłowiańskiej polityki kulturowej, która dziś wydaje się niczym innym jak kulturową polityką odporową wobec takich polityk, jak pangermanizm, madziaryzm czy islamizacja.

Pan-naród stwarzał zaplecze polityczne dla rozwoju języków i uzyskania autonomii istnień kulturowych poszczególnych narodów (słowiańskich). Aby jednak stało się to możliwe, istotne było wyłonienie dla tej formacji myślowej dwóch kwestii: polityczności i pedagogiczności świata-kultury, by umożliwić współ-bycie narodom w obrębie pan-narodu na mocy zasad: przygodności, regularności i wzajemności. Jedność narodu słowiańskiego rozumiana była

76 Ale też: implicite zawarta jest tu uniwersalistyczna zasada sprzeciwu wobec europocentrycznego modelu kultury oświeceniowej, który dąży do stworzenia homogenicznego świata. Por. przypis nr 32.

77 J. Kollár: O literackiej wzajemności między różnymi szczepami i narzeczami narodu słowiańskiego (Peszt 1837). W: J. Kollár: Wybór pism. Wrocław 1954, Zakład Narodowy im. Ossolińskich.

78 J. M. Černý: Slovanský sjezd v Praze roku 1848. Na památku čtyřicetiletou vypravuje a dokládá př́slušnými akty. Praha 1888, Nakladatel M. Knapp; J. Moraczewski: Opis pierwszego Zjazdu Stowiańskiego. Poznań 1848, Nakładem N. Kamieńskiego i Spółki. 
jako idea pierwotna, która dla wszystkich Słowian okazać się miała użyteczną. Trudność wcielenia tej idei w życie związana była z niechęcią jednych i opaczną przychylnością drugich ${ }^{79}$.

Tym, co scalać miało wszystkie szczepy słowiańskie w obrębie pan-narodu, była idea wzajemności - o czym pisałam wyżej. Szło w niej o wspólne przyjmowanie, wzajemną wymianę oraz wspólne korzystanie z poszczególnych kultur narodów słowiańskich. Swoistą metodą tej idei miało być połączenie działań i jednoczesne współzawodnictwo, których celem był rozkwit wszystkich kultur (literatur) słowiańskich oraz równoczesny rozwój kultury ogólnosłowiańskiej, która w myśli Kollára również jawiła się jako uniwersum wewnętrznie zróżnicowane. Idzie też o polityczność idei wzajemności, jako możliwość działania i mówienia, a więc uznania poszczególnych narodowości i ich języków przy wierności i posłuszeństwie władzy kraju (państwa), który dana narodowość zamieszkiwała. W żaden sposób nie szło tu o realizację polityki jako sztuki administrowania granicami (jako separacji) ${ }^{80}$. Trzeba podkreślić, że polityczny wymiar kulturowej wzajemności poszczególnych narodów słowiańskich wiązał się też z pomocą w doskonaleniu się (kultura/ sztuka) i wymianie języków ${ }^{81}$, to miało przysłużyć się rozwojowi języków, sztuki i umiejętności ważkich dla kultury całego pan-narodu ${ }^{82}$.

Realizacja idei wzajemności wymaga pewnej gotowości i politycznej oraz kulturowej dojrzałości poszczególnych narodów, które miały budować kulturę pan-narodu. Wymagało to porzucenia nacjonalistycznych aspiracji narzucania własnej narodowej kultury innym narodom i uznawania jej za reprezentatywną/wzorcową dla całego pan-narodu. Takie aspiracje „znieważały" zasadę odrębności/autonomii języków i kultur w obrębie pan-kultury ${ }^{83}$.

Myśl Kollára skupiała się na próbie rozwiązania sporu między przywiązaniem i miłością do/dla własnej odrębności kulturowej i językowej a możliwością stworzenia wspólnej przestrzeni pan-kultury, w której poszczególne narody zachowają swe odrębności i na zasadzie wzajemności będą mogły dokonywać „wymiany” swego kulturowego i językowego potencjału, po to by: rozwijać same siebie (przez zasilenie z zewnątrz na mocy dobrowolności)

79 J. Kollár: O literackiej wzajemności między różnymi szczepami i narzeczami narodu słowiańskiego (Peszt 1837). cyt. wyd., s. 4-6.

80 Tamże, s. 7-9.

81 Tamże, s. 22.

82 Tamże, s. 25.

83 Tamże, s. 8-12. 
i by rozwijać swą wspólną przestrzeń pan-kultury. Ale: to przede wszystkim ludzie decydują o tym, jaki duch i jakie życie zasiedla ich narodowe kultury oraz o tym, jaka będzie ta wspólna uniwersalna przestrzeń pan-kultury. Jeśli bowiem przywiązanie do własnej kultury i języka realizowane jest w duchu ciasnego partykularyzmu i separatyzmu, to wytwarzanie przestrzeni wzajemnej wymiany staje się niemożliwe z tej przyczyny, że zmienia się ona w obszar rywalizacji i walki o dominację własnej kultury i języka nad innymi kulturami i językami ${ }^{84}$. Jest to więc polityczna sytuacja poniżania praw nie tylko poszczególnych narodów, ale także praw pojedynczych osób ${ }^{85}$.

Batalia rozgrywa się zatem o ideę, w przestrzeni której uznane zostaną odrębności językowe i kulturowe poszczególnych narodów, tak aby dzięki mowie i działaniu oraz we współuczestnictwie narody mogły się rozwijać w autonomii i jednocześnie w uniwersalistycznej wewnętrznie zróżnicowanej wspólnocie kulturowo-politycznej. Logika współuczestnictwa nie może sprowadzać się do wzajemnego naśladownictwa, gdyż współuczestnictwo jest moralno-intelektualnym konstruktem, który jest współ-tworzony dzięki samodzielnej językowej twórczości (gdyż tu ujawnia się „duch narodu”) i samodzielności działania przy równoczesnym uznaniu całości pan-kulturowej (tu: Słowian) oraz całości kulturowej i historycznej świata ${ }^{86}$. Jakkolwiek kultura w dużej mierze dzieje się w obrębie języka, to Kollár dostrzega jej aspekt edukacyjny ${ }^{87}$. Wytworzenie przestrzeni wymiany i współdziałania pozwoli poszerzyć zakres kształcenia przez stworzenie możliwości dostępu nie tylko do dorobku kulturowego własnego narodu, ale także do dorobku innych narodów. Człowiek otrzymuje najpełniejszą możliwość kształcenia tylko przez kontakt z kulturową całością ludzkości. Człowiek nie dojrzewa w sensie ludzkim, jeśli nie ma w swej edukacji dostępu do wewnętrznie zróżnicowanego uniwersum świata i kiedy nie może z niego korzystać. Edukacyjne zamknięcie we własnej kulturze i języku swoiście zatrzaskuje człowieka

84 Przykładem zmiany idei słowianofilstwa i panslawizmu w przestrzeń artykulacji partykularnych interesów jednego narodu jest przeformułowanie, do jakiego doszło w idei słowianofilstwa i panslawizmu w Rosji, kiedy słowianofilstwo zmieniło się w rusofilstwo, a panslawizm w pan-rosyjskość. Pierwsze służyło wewnętrznej integracji narodu rosyjskiego, drugie stanowiło ideologiczny argument dla polityki zagranicznej Rosji. Przemiana ta stała się w Rosji jaskrawo widoczna po wojnach krymskich, z których Rosja wyszła pokonana polityczne i militarnie.

85 J. Kollár: O literackiej wzajemności między różnymi szczepami i narzeczami narodu stowiańskiego (Peszt 1837). cyt. wyd., s. 41 i n.

86 Tamże, s. 50.

87 Także ekonomiczny i materialny. 
w partykularnym i separatystycznym nacjonalizmie i swoiście naznacza go pragnieniem wywyższania się ponad inne narody ${ }^{88}$.

Tak więc tym, co stanowi o odrębności narodu, jest jego kultura oraz język. Dla Kollára - pobodnie jak wcześniej dla Herdera - świat ma wymiar językowy, a kultura dzieje się w obrębie języka, choć materializuje się ona w postaci innych trwałych wytworów. Kultura łączy się z polityką i politycznością w sensie prawa stanowienia i autonomii oraz możliwości działania. Szczególnym wymiarem polityczności jest uznanie odrębności językowej i prawa do istnienia we wspólnej politycznej przestrzeni wielu języków. Stąd między innymi założenia Kollára o konieczności kształcenia językowego, po to, by rozumieć mowę swych braci Słowian. Chodzi też o pedagogiczność zawartą w myśli Kollára: człowiek jest postrzegany przez pryzmat jego kulturowego rozwoju w powiązaniu z procesami edukacyjnymi, które realizowane są w rodzinie, wspólnocie, szkole, oraz w nauce. Miejsca te mogą albo sprzyjać, tzn. otwierać człowieka na łączność z kulturową całością świata, albo mogą go zatrzaskiwać w jednostkowym oderwaniu od całości świata i ciasnym przywiązaniu do „swego”. Miejsca te mogą też wydziedziczać człowieka z jego narodowej kultury i wytwarzać w nim przekonanie, że od własnego języka lepszy jest inny język, a od miłości kultury własnej lepsza jest miłość kultury innej ${ }^{89}$. Pedagogiczność i polityczność myślenia Kollára sprowadza się m.in. do okrywania "geniuszu” własnej kultury oraz "geniuszu” innych kultur. Nie ma tu ani kultur gorszych ani lepszych. Pomniejsze kultury tworzą wewnętrznie zróżnicowane uniwersum całości kulturowej świata. Zadaniem polityki i edukacji jest pozwolić człowiekowi na dostęp do tego ogólnoludzkiego zaplecza, które w swej istocie stanowi właśnie o jego ludzkości. Narody, podobnie jak poszczególni ludzie, mogą się wzajemnie rozwijać (także gospodarczo), jeśli będą się wzajemne wspierały oraz wzajemnie uczyły ${ }^{90}$.

\section{Młodokaszubów kulturowa polityka jedności, jako możliwość relacji: region-państwo}

Młodokaszubi byli ruchem kulturowym, a właściwie politycznym, którego zasadniczym celem było zachowanie kulturowej tożsamości Kaszub. Szalenie

88 J. Kollár: O literackiej wzajemności między różnymi szczepami i narzeczami narodu słowiańskiego (Peszt 1837). cyt. wyd., s. 56-57.

89

Tamże, s. 59 i n.

90 Tamże, s. 62-92. 
kłopotliwym punktem spornym relacji kaszubskich i polskich była kwestia językowa i to właśnie jej „rozwiązanie” determinowało od „zawsze” styl myślenia o Kaszubach: bądź w politycznej (państwowej) jedności z Polską, bądź w politycznej (państwowej) odrębności (autonomiczności) wobec Polski, bądź w politycznej (państwowej) separacji (rozerwaniu) z Polską.

\subsection{Polityczność kultury w myśli młodokaszubskiej}

Aby lepiej zrozumieć problem, wobec którego stanęli Młodokaszubi, trzeba przywołać kilka niezbędnych faktów dotyczących językowych relacji kaszubsko-polskich, i trzeba myślowo sięgnąć do przekonań Ceynowy. Ceynowa budował swój program społeczno-kulturowy i polityczny na doktrynie Kollára i pośrednio na filozofii Herdera ${ }^{91}$, która „poruszyła” Słowian w kierunku stworzenia idei kultury pan-narodu słowiańskiego, budowanej na tezie odrębności (autonomii) mniejszych kultur słowiańskich oraz ich wzajemności. Ceynowa uznał język kaszubski za słowiański ${ }^{92}$. Wprost pisze on o języku/mowie kaszubskosłowiańkiejej i uznaje jej odrębność wobec języka polskiego, i jednocześnie walczy z przekonaniem, że język kaszubski jest zepsutą mową polską ${ }^{94}$. Okres rozbiorowy przyczynił się do wyostrzonego postrzegania kwestii kaszubskiej jako polskiej przez propolskie środowiska; wszelkie działania, których celem było zaznaczenie kaszubskiej odrębności językowej, uznawane były za działania separatystyczne, i to w pejoratywnym znaczeniu: jako zdrada polskości. Ceynowa pisał o szczególnej sytuacji politycznej Kaszubów związanej z przynależnością państwową: idzie o Kaszu-

91 Chociaż nie wiadomo, czy sam bezpośrednio sięgał do dzieł tego filozofa. Jednak to filozofia Herdera stanowi myślową podstawę działań i myśli słowianofilów i panslawistów czeskich, z którymi Ceynowa był związany, i z których doświadczeń korzystał.

92 Przykładowo: Stanisław [F. Ceynowa]: Wuvagi nad móva kaszebska. W: Stanisław [F. Ceynowa]: Trze rosprawe voros Wojkasen [F. Ceynowa]: Kile słov wó Kaszebach e jich zemji. Kraków 1850, Nakładem Księgarni i Czcionarni pod Sową, s. 39; L. Roppel: Dr Florian Ceynowa na miarę stowiańską. Dwa listy Cenôvy do Ramutta. „Klëka” 1939, nr 3, s. 4.

93 Dr. Florjan Cenôva [F. Ceynowa]: Zvéczaje é wòbéczaje Kaszébskostovjnskjèho narodé. „Skôrb Kaszébskosłovjnskjè mòvé”, Pjrszè xęgj pjrszi seszét. Svjecè 1866, Czôrnoxężnik J. Hauffe, s. 97.

94 Stanisław [F. Ceynowa]: Wuvagi nad móva kaszebską. cyt. wyd., s. 48. 
bów-Niemców oraz o Kaszubów-Polaków ${ }^{95}$, jednocześnie - jakby mimochodem - pisząc o geografii i historii Kaszubów przywołuje tytuł książki: Dzieje narodu polskiego ${ }^{96}$, co wskazywać może na wiązanie przez niego dziejów narodu kaszubskiego z dziejami narodu polskiego ${ }^{97}$. Jednakże Ceynowa zarzuca Polakom nie tylko to, że zbyt mało interesowali się sprawami kaszubskimi i niewiele wiedzieli o kulturze tego narodu ${ }^{98}$, ale przede wszystkim to, że wyśmiewali się oni z mowy kaszubskiej, nazywając ją właśnie zepsutą mową polską ${ }^{99}$. Kłopotem w relacjach kaszubsko-polskich był nie tylko język, ale także stanowość (chłopskość) oraz niski poziom wykształcenia większości Kaszubów - a w zasadzie brak wykształcenia warstw chłopskich. Język kaszubski - jako zepsuta mowa polska - miał właśnie zaświadczać o chłopskości i braku wykształcenia, ale nie tylko to było udręką Ceynowy: chodziło o to, że to Polacy nie chcieli się bratać z Kaszubami - ciemnymi chłopami ${ }^{100}$. Ceynowa w swych przekonaniach był demokratą, co w jego my-

\footnotetext{
95 Wojkasen [F. Ceynowa]: Kile słov wó Kaszebach e jich zemji. cyt. wyd., s. 18-19.

96 Tamże, s. 19.

97 Por. także: Wójkasin [F. Ceynowa]: Kaszebji do Pólochov. „Szkoła Narodowa” 1850, nr 10, s. 39-40.
}

98 O problemie zapomnienia o Kaszubach pisali m.in.: Wójkasin [F. Ceynowa]: Kaszebji do Pólochov. cyt. wyd., s. 39-40; J. Karnowski: Moja droga kaszubska. Gdańsk 1981, Wydawnictwo Zrzeszenie Kaszubsko-Pomorskie Oddział Miejski w Gdańsku, s. 29; Janowicz [J. Karnowski]: Nowe prądy na Kaszubach. „Prąd. Miesięcznik Społeczny i Literacko-Naukowy” 1910, R. 2, nr 6, s. 213-215; P. W.: Smutnô prôwda. „Klëka” 1938, R. 2, nr 7, s. 2.

99 Wójkasin [F. Ceynowa]: Kaszebji do Pólochov. cyt. wyd.; Stanisław [F. Ceynowa]: Wuvagi nad móvą kaszebską. cyt. wyd., s. 48; L. Roppel: Dr Florian Ceynowa na miare słowiańską. Dwa listy Cenôvy do Ramułta. cyt. wyd. s. 4; S. Ramułt: Wstęp. Stanowisko języka pomorskiego w gronie języków słowiańskich. W: S. Ramułt: Słownik języka pomorskiego czyli kaszubskiego. Kraków 1893, Wydawnictwo Akademia Umiejętności, s. XXXVII; [bez autora]: Ruch młodokaszubski. „Gryf. Pismo dla spraw kaszubskich” 1909, nr 7, s. 192-198.

100 Istotnym kontekstem - pominiętym z powodu ograniczonej formuły testu - dla analizy myśli Ceynowy jest ówczesna rzeczywistość polityczna, której logikę ujawniła klęska powstania listopadowego i klęska Wiosny Ludów. Wydarzenia te nie przyniosły Polsce oczekiwanej wolności, ale bezlitośnie odsłoniły feudalne struktury społeczeństwa polskiego. Wydaje się, że główną przyczyną klęski powstania listopadowego i Wiosny Ludów był fakt, że problem wyzwolenia był wyłącznie priorytetem elity: arystokratów i szlachty. Warstwy chłopskie nie były w najmniejszym stopniu zainteresowane niepodległością Polski, gdyż obawiali się powrotu Polski przedrozbiorowej wiązanej z niewolni- 
śli przekładało się na konieczność przyznania chłopom praw obywatelskich oraz budzenia ich świadomości społeczno-politycznej, a także kształcenia. Dla Ceynowy podstawą porządku społecznego był rozsądek (wykształcenie) oraz równość ludzi niezależnie od ich stanowego pochodzenia. Ceynowa jako wykształcony i światły Kaszuba - zrywał z feudalizmem i chłopskim niewolnictwem, a polska elita (wykształcona i niewykształcona szlachta oraz arystokracja) nie potrafiła zrezygnować z różnic stanowych. Stąd to z winy Polaków, a nie Kaszubów oba narody muszą tylko współistnieć obok siebie, i to nie z powodu różnicy kulturowej i językowej, ale z powodu zapatrywań na podstawowe kwestie ustroju społeczno-politycznego. Sytuacja ta była nieszczęściem obu narodów i - w przekonaniu Ceynowy - trwać ona będzie tak długo, jak długo w relację tę nie wmiesza się inny naród słowiański ${ }^{101}$ z lepszymi zasadami ${ }^{102}$.

czą zależnością chłopa od pana. Na problem ten zwraca uwagę m.in. Demokrata Polski, emigracyjne czasopismo, na łamach którego publikowano szereg tekstów krytycznych opisujących rzeczywistą kondycję feudalnego społeczeństwa polskiego. W pierwszej połowie XIX wieku wśród arystokracji dominował pogląd, że lud (chłopi) nie może być podstawą wyzwolenia Polski i że nie istnieje żadna polityczna przesłanka, w myśl której można nadać ludowi prawa polityczne. Podstawą tychże twierdzeń było przekonanie, że Polskę wyzwolić mogą tylko posiadające i wykształcone warstwy społeczne. Ruchy demokratyczne zwróciły się zatem ku ludowi i w swych programach podjęły batalię o nadaniem ludowi praw obywatelskich. Patrz: [bez autora]: Jaka jest doktryna arystokracyi. „Demokrata Polski. Pismo polemiczne” 1838, tom 2 (od 7 listopada 1838 do 27 stycznia 1840 roku), s. 53-55; [bez autora]: Nowe plany arystokracyi. „Demokrata Polski. Pismo polemiczne" 1838, tom 2 (od 7 listopada 1838 do 27 stycznia 1840 roku), s. 153-160, szczególnie s. 157 i n.; [bez autora]: Niewolnictwo w Polsce. Licytacya na duszę Józefa Markowskiego. „Demokrata Polski. Pismo polemiczne” 1838, tom 2 (od 7 listopada 1838 do 27 stycznia 1840 roku), s. 12-13; [bez autora]: Arystokracya i emancypacja ludu w Polsce. O emancypacji ludu w Polsce. „Demokrata Polski. Pismo polemiczne” 1840, tom 3 (od 14 lutego 1840 do 21 maja 1841 roku), s. 17-19 oraz 89-90. Dla porównania także: Wójkasin [F. Ceynowa]: Kaszebji do Pólochov. cyt. wyd., s. 39-40; [bez autora]: Odrodzenie Kaszub. „Gryf. Pismo dla spraw kaszubskich” 1909, nr 3, s. 65-73.

101 Słowa te zostały opublikowane w 1868 r., po Kongresie Słowiańskim w Moskwie w $1867 \mathrm{r}$. Informacja ta jest o tyle istotna, że Ceynowie zarzuca się sympatie prorosyjskie. Ceynowa, który utrzymywał kontakty naukowe z Petersburską Akademią Nauk, uczestniczył w Kongresie Moskiewskim, wyjechał jednak stamtąd przed zakończeniem obrad, oburzony tego upolitycznieniem. Wydaje się więc, że nie mogło chodzić o interwencję narodu rosyjskiego.

102 Dr. Florjan Cenôva, Wòjkasin ze Sławòszéna [F. Ceynowa]: Rozmòva Kaszèbé 
Językowe stanowisko Ceynowy znalazło swą kontynuację w pracach Stefana Ramułta, który uznał język kaszubski za odrębny wobec języka polskiego $^{103}$. Uważał on, że nie jest to język „ubogi”, a wręcz przeciwnie: „góruje nad polskim bogactwem dźwięków i form". Jest to język używany przez warstwy niższe oraz średnie ${ }^{104}$ zaś afiliację państwową (polską bądź niemiecką, co przekładało się na odpowiedni język ogólnopaństwowy) uznał za kwestię politycznego wyboru bądź konieczności ${ }^{105}$.

Fryderyk Lorentz ${ }^{106}$ - podobnie jak Ramułt i Ceynowa - uznał odrębność języka kaszubskiego wobec polskiego, a także jego odrębność wobec języka niemieckiego ${ }^{107}$.

s Pòlôchę. „Skôrb Kaszébskosłovjnskjè mòvé”, Pjrszè xęgj drégj seszét. Svjecè 1868, Czôrnoxężnik J. Hauffe, s. 197-198.

103 S. Ramułt: Wstęp. Stanowisko języka pomorskiego w gronie języków słowiańskich. cyt. wyd., s. XXXIX-XLIV.

104 S. Ramułt: Wstęp. Wiadomości ogólne o Kaszubach, W: S. Ramułt: Statystyka ludności kaszubskiej. Kraków 1899, Wydawnictwo Akademii Umiejętności, s. 33; S. Ramułt: Przedmowa. W: S. Ramułt: Słownik języka pomorskiego, czyli kaszubskiego. Kraków 1893, Wydawnictwo Akademia Umiejętności, s. X-XI, tenże: Wstęp. Dźwięki języka pomorskiego. Iloczas. Akcent, W: S. Ramułt: Słownik jezzyka pomorskiego, czyli kaszubskiego. cyt. wyd., s. XXI-XXII.

105 S. Ramułt: Przedmowa. W: S. Ramułt: Statystyka ludności kaszubskiej. cyt. wyd., s. 2 i n.; tenże: Wstęp. Wiadomości ogólne o Kaszubach. cyt. wyd., s. 30-33, 33-36; tenże: Wstęp. Obecne terytorium etnograficzne szczepu pomorskiego. Wiadomości statystyczne. W: S. Ramułt: Stownik języka pomorskiego, czyli kaszubskiego. cyt. wyd., s. XIX.

106 Niemcy na początku dwudziestego wieku podjęli szerokie badania nad kulturą Kaszub („badanie właściwości ludu kaszubskiego”). W 1907 roku w Kartuzach powstało stowarzyszenie: Verein für kaschubische Volkskunde. Na jego czele stanął Fryderyk Lorentz. Zadaniem stowarzyszenia było zbieranie materiałów z zakresu ludoznawstwa kaszubskiego. Początkowo stowarzyszenie realizowało zadania naukowe i skupiało w swych szeregach obok Kaszubów-Niemców także Kaszubów-Polaków (m.in. Aleksander Majkowski był członkiem tego stowarzyszenia), później natomiast zatraciło swój naukowy charakter i stało się elementem polityki germanizacyjnej na Kaszubach. Takie posunięcie wiązało się także z wykluczeniem z członkowska osób zainteresowanych wyłącznie badaniami naukowymi.

107 F. Lorentz: Obszar mowy kaszubskiej. „Gryf. Pismo dla spraw kaszubskich” 1909, nr 4, s. 97-101; H. Ułaszyn: Dzieje języka polskiego Brücknera. „Rocznik Slawistyczny" 1908, tom 1, s. 82; K. Nitsch: Charakterystyka porównawcza dyalektów zachodnio-pruskich. „Rocznik Towarzystwa Naukowego w Toruniu” 1906, Tom XIII, s. 163. 
Z kolei teza o tym, że język kaszubski jest „lichą mową polską”, a sami Kaszubi powinni pilnie się uczyć polskiego, aby władać nim tak dobrze jak „Polacy z Warszawy”, znalazła swą kontynuację w myśli Hieronima Jarosza Derdowskiego ${ }^{108}$.

Piotr Iwan Prajs uznał język kaszubski za narzecze języka polskiego ${ }^{109}$. Podobne stanowisko reprezentuje Kazimierz Nitsch ${ }^{110}$. Z kolei Aleksander Brückner wysnuł wniosek, że język kaszubski jest gwarą staropolską ${ }^{111}$.

Młodokaszubi stanęli zatem wobec szczególnie trudnego i, jak się wydawało, nierozwiązywalnego problemu statusu języka kaszubskiego wobec polskiego $^{112}$. W ówczesnych badaniach i literaturze językoznawczej obecne bowiem były stanowiska: a) język kaszubski jako odrębny/autonomiczny wobec języka polskiego, co stanowić mogło podstawę realizacji zasady wzajemności (kooperacji) bądź co najmniej współistnienia obu narodów w ramach państwowości; b) język kaszubski jako odrębny/autonomiczny wobec języka polskiego, co prowadzić mogło do separacji (oderwania od siebie) obu narodów; c) język kaszubski jako narzecze (dialekt) języka polskiego, co implikować mogło konieczność uznania języka polskiego jako lepszego i w efekcie asymilację językową. Wzmożona polityka germanizacyjna na Kaszubach i na pozostałych ziemiach zaboru pruskiego wytworzyła w świadomości Polaków i wielu Kaszubów prze-

108 H. J. Derdowski: Ò panu Czôrlińsczim, co do Pùca pò sécë jachôt. Opr. J. Samp, J. Treder, E. Gołąbek. Gdańsk 2007, Wydawnictwo Instytutu Kaszubskiego, s. 315-316.

109 P. I. Prajs: Rzecz o języku kaszubskim. W: Wojkasen [F. Ceynowa]: Kile stov wó Kaszebach e jich zemji. Tudzież rzecz o języku kaszubskim ze zdania sprawy Prajsa. Kraków 1850, Nakładem Księgarni i Czcionarni pod Sową, s. 35-36.

110 K. Nitsch: Charakterystyka porównawcza dyalektów zachodnio-pruskich. cyt. wyd., s. 161-194; tenże: W sprawie pisowni kaszubskiej. „Gryf. Pismo dla spraw kaszubskich" 1910, nr 1, s. 5-9.

111 A. Brückner: Dzieje języka polskiego. Lwów - Warszawa 1913, Towarzystwo Nauczycieli Szkół Wyższych we Lwowie, Składy Główne w Księgarniach: Gubrynowicza i Syna we Lwowie, Gebethnera J. Wolffa w Warszawie, s. 10. [Wydanie pierwsze: Lwów -Warszawa 1906 r.].

112 Janowicz [J. Karnowski]: Zdania o stosunku językowym ludności kaszubskiej do polskiej. „Gryf. Pismo dla spraw kaszubskich” 1910, nr 4-5, 144-151 (cz. 1); tenże: Zdania o stosunku językowym ludności kaszubskiej do polskiej. „Gryf. Pismo dla spraw kaszubskich" 1910, nr 7, s. 192-199 (cz. 2); tenże: Zdania o stosunku jezzykowym ludności kaszubskiej do polskiej. „Gryf. Pismo dla spraw kaszubskich” 1910, nr 9, s. 260-266 (cz. 3); tenże: Zdania o stosunku ludności kaszubskiej do polskiej pod względem językowym. „Gryf. Pismo dla spraw kaszubskich” 1910, nr 12, s. 358-360 (cz. 4). 
konanie, że autonomizacja języka kaszubskiego jest jednoznaczna z dążeniami separatystycznymi i wiązać się musiała niezaprzeczalnie z oderwaniem Kaszub od państwa polskiego i włączeniem ich w obręb państwa pruskiego.

Język - jako wytwór kultury i jednocześnie to, co kulturę tworzy - w stosunkach kaszubsko-polskich stanowił (i nadal stanowi) ważki element polityki kulturowej. Wydaje się, że polityczny aspekt kultury (tu języka) nie byłby tak wyraźny, gdyby nie fakt politycznego zagarnięcia ziem polskich przez inne państwa (mocarstwa). Wydaje się również, że problem ten pozostałby lokalnym, gdy w podobnej sytuacji nie znalazły się inne narody ówczesnej Europy. Fenomen Młodokaszubów konstruuje się na sytuacji, kiedy język i kultura stają się kwestią nie tyle dociekań naukowych czy filozoficznych, ale stanowią ważki kontekst i podstawę politycznych wyborów.

Dla Młodokaszubów (podobnie jak wcześniej dla innych myślicieli kaszubskich) charakterystyczny był swoisty niedostatek zaplecza metodologicznego dla możliwości teoretycznych i politycznych rozwiązań sporu kaszubskość - polskość. Jego istota wynikała z nieobecności w ówczesnej wiedzy jakiejkolwiek koncepcji dwukulturowości i dwutożsamości. Herder - jak ukazałam wyżej - odsłonił językowy charakter kultury, językowy charakter tożsamości narodów (zwłaszcza małych, dla których język jest największym skarbem) i osób oraz ukazał świat jako kulturę a także obalił mit uniwersalistycznego wzorca kultury na rzecz tezy o tym, że każda kultura wytwarza właściwy sobie wzorzec. Kollár rozwinął filozofię Herdera i stworzył zasady kooperacji narodów, które dzięki idei wzajemności mogły się rozwijać i wzajemnie bogacić. Analiza kwestii politycznych i pedagogicznych programu Kollára pozwala uznać go za możliwą propozycję idei międzykulturowości, a obecne w programie przejawy edukacyjne i polityczne pozwalają przyjąć ten program także jako program edukacji międzykulturowej. Jednak myśl Herdera, podobnie jak myśl Kollára (i innych panslawistów oraz słowianofilów) nie dostarczała podstaw teoretycznych dla rozpoznania i rozważenia kwestii afiliacji do dwóch kultur jednocześnie. Jakkolwiek dopuszczali oni możliwość życia w obrębie własnej narodowej kultury i jednocześnie w administracyjnym obrębie państwa, tworzonego przez inny naród. Przynależność państwowa stawiła konsekwencję zdarzeń historycznych czy geograficznych, zaś odmienną sprawą była przynależność kulturowa do własnego narodu.

Trzeba podkreślić, że jakkolwiek na poziomie „zwyczajnego życia” - ateoretycznych praktyk społecznych - wielu Kaszubów czuło się jednocześnie Polakami, to w sytuacji potrzeby teoretycznych i politycznych konceptuali- 
zacji spór był nierozwiązywalny: autonomiczność kultur i języków stanowiła niemożliwy do pogodzenia dylemat. Właśnie wobec takiego problemu metodologicznego stanęli Młodokaszubi, którzy nie chcieli asymilacji w kulturę i język polski, i równocześnie nie chcieli separacji od kultury i języka polskiego. Byli przy tym świadomi, że ich przekonania na temat związków języka kaszubskiego i polskiego będą miały znaczenie przede wszystkim polityczne.

Młodokaszubi dostrzegali istotę polityczności życia: fakty społeczne, naukowe, oświatowe czy literackie „ujawniły” swe „nowe/inne” znaczenia zależnie od kontekstu, w jakim były lokowane: zatem to kontekst budował znaczenie, tym samym zmiana kontekstu generowała zmianę znaczenia. W konsekwencji okazywało się, że od tego, jak rozumiano wyżej wymienione kategorie, zależał bieg ludzkiego życia czy bieg życia danej społeczności. Polityka dowodziła, że znaczenia takich kategorii, jak choćby „język kaszubski", nie były konsekwencją oddolnych społecznych negocjacji (nie chodziło o to, jak je rozumieli ludzie) i nie były one również wytworem dociekań naukowych (nie chodziło też o „odkrywanie” prawdy o nich), ale ich rozumienie (znaczenie) było wynikiem nadania administracyjnego w toku biurokratycznych procedur. Logika przypisywania znaczenia do konkretnej kategorii ujawniała się w politycznych losach całych społeczności i pojedynczych osób. W tym właśnie sensie polityka przestała oznaczać wyłącznie przynależność partyjną czy sztukę zarządzania (administrowania) państwem ${ }^{113}$. Ale wiązała się ona z politycznością kultury, która tylko pozornie wydawała się (i nadal wydaje) nie-polityczna. Celem działań politycznych (jawnych bądź ukrytych) może być m.in. wyrywanie z „pokładów” jednej/własnej kultury i wdrożenie do kultury nowej/obcej. Chodzi tu przede wszystkim o zmianę fundamentów dla tworzenia i trwania tożsamości: oderwanie od dotychczasowego pojmowania siebie i nadanie czy też narzucenie innego/nowego rozumienia siebie $^{114}$. Kaszubi na przełomie XIX i XX wieku znaleźli się w szczególnej sytuacji: mogli doświadczyć tego, jak ich życie zmienia się w sytuacji wikłania sporów naukowych w działania polityczne. Sprawa dotyczyła przywołanego w tekście językoznawczego sporu o status języka kaszubskiego. Uznanie bowiem przez grupę badaczy języka kaszubskiego jako odrębnego względem języka polskiego z „należytą atencją” znalazło swą finalizację w kulturowej

113 Ś. Sudomski [A. Majkowski]: Zjazd młodokaszubów. „Gryf. Pismo dla spraw kaszubskich" 1912, nr 7, s. 180.

114 Ś. Sudomski [A. Majkowski]: O przyszłość ruchu młodokaszubskiego. „Gryf. Pismo dla spraw kaszubskich" 1912, nr 3, s. 53 i n. 
polityce germanizacyjnej ${ }^{115}$. Zaborca uznał, że skoro język kaszubski jest ojczystą mową Kaszubów, to język niemiecki posiada dokładnie taki sam status jak wcześniej język polski: był językiem administracji, literatury, szkoły oraz Kościoła. Skoro więc Kaszuby administracyjnie znalazły się w obrębie państwa pruskiego, a tu językiem ogólnopaństwowym był język niemiecki, to został on automatycznie uznany za język państwowy Kaszubów ${ }^{116}$. Logika ta otworzyła nowe wrota do działań germanizacyjnych.

Wydaje się, że Aleksander Majkowski i Jan Karnowski (twórcy ruchu Młodokaszubów) byli świadomi tej swoistości polityki: tego, że jakkolwiek jest to jakiś kulturowy wymiar życia człowieka, to znacząco determinuje jakość tego życia. Polityka to przestrzeń, w której ścierają się rozmaite prawdy, i wybór którejkolwiek implikuje jakość życia. Albo inaczej: warunkuje tożsamość osobistą i zbiorową. Sytuacja Kaszubów była szczególna, gdyż większość z nich wybrała polskość obok kaszubskości. Natomiast polityka okazała się szczególnego rodzaju przestrzenią, w której wieloznaczność statusu języka kaszubskiego okazała się skutecznym orężem dla kulturowej polityki germanizacyjnej i jednocześnie była szczególnie niebezpieczna dla słabych politycznie i militarnie Kaszub oraz Polski, z którą Kaszubi się identyfikowali. Dlatego też Majkowski wraz z Karnowskim musieli zrekonstruować taką koncepcję kooperacji kaszubsko-polskiej, by stała się ona legitymizacją dla wyrażanej woli przynależności do Polski. Prymarne stało się zatem rozwiązanie kwestii statusu języka kaszubskiego w relacji do polskiego i jednoznaczne oczyszczenie go wieloznaczności.

Karnowski był świadom konsekwencji uznania odrębności języka kaszubskiego i zapytywał o to, jakie to będzie miało konsekwencje dla polskości Kaszubów? I jakkolwiek Kaszubi mają prawo „utrzymania i wydoskonalenia języka kaszubskiego”, to tzw. „kwestia kaszubska” wiązała się z obecnością kultury i języka polskiego na Kaszubach na prawie „tożsamości i jedności mowy kaszubskiej z polską"117. Idzie zatem o jedność i tożsamość języka kaszubskiego z polskim. Wobec tego metodologicznym zadaniem, jakie postawili przed sobą Karnowski, Majkowski i inni Młodokaszubi, było „uzasad-

115 [bez autora]: Zwycięstwo hakatyzmu nad nauką. „Gryf. Pismo dla spraw kaszubskich" 1910, nr 10, s. 289-294.

116 Janowicz [J. Karnowski]: Nowe prady na Kaszubach. cyt. wyd. [bez autora]: Dive et impera. „Gryf. Pismo dla spraw kaszubskich” 1909, nr 2, s. 33. [33-41].

117 J. Karnowski: Moja droga kaszubska. cyt. wyd., s. 26-32. Redakcja „GRYFA”: Nasz program. „Gryf. Pismo dla spraw kaszubskich” 1908, nr 1, s. 2. 
nienie kwestii kaszubskiej jako kwestii polskiej [...] przez badania naukowe bądź w inny sposób [...]"118, choćby przez umocowanie w tradycji119. Uznanie jedności kultury i języka kaszubskiego z polskim pozwoliło skonstruować organiczny model kultury ${ }^{120}$, który równocześnie akcentował wszystko to, co dla „duszy kaszubskiej powinno być drogie” (a więc: ziemia [w sensie terytorium], tradycja, mowa, obyczaje) oraz „wspólność narodową i kulturalną z Polską"121. Wypracowany model kultury budowany był na tezie, że kulturę ogólnopolską, tzw. „pierwiastki ogólnopolskie”, należy oprzeć i rozwijać na kulturze regionalnej, czyli „swojskiej”, a więc na tzw. „pierwiastkach swojskich”, zaś „[...] ideały kaszubskie i ogólnopolskie trzeba organicznie spoić”. To spajanie „pierwiastka kaszubskiego i polskiego” stanowiło podstawę myślenia Młodokaszubów, ze wszystkimi tego konsekwencjami, a wyrażało się ono w haśle: „co kaszubskie, to polskie”122.

Myśl młodokaszubska stanowi zatem wypadkową skrajnych ideologii (1) oderwania ideałów kaszubskich od ideałów polskich; oraz (2) asymilacji, jako konsekwencji ignorancji dla ideałów kaszubskich. Relacja ludowej kultury kaszubskiej do kultury ogólnopolskiej rozumiana była przez Młodokaszubów jak stosunek „gałęzi do drzewa”. Gałąź Kaszubka była chora, choć przenikały ją „soki kursujące po całym ciele” ${ }^{123}$. Zadaniem ruchu było „usunięcie przyczyn tej martwoty, tak, iż za jego staraniem gałąź ta wydać ma owoc jej rodzajowi właściwy"124. Mogło się to dokonać jedynie przez pracę pedagogiczną, „mająca na celu sanacyę duszy kaszubskiej i wyrobienie charakteru". Zdefiniowanie i rozpoznanie ideałów kaszubskich miało pełnić rolę „medycyny”, gdyż powinny być one zaszczepione i pielęgnowane tak długo, jak długo „ludność kaszubska nie przebudzi się do samodzielnego życia kulturalnego w tym znaczeniu, że przestanie być biernym, lecz stanie się czynnym członkiem w organizmie kultury polskiej"125.

118 J. Karnowski: Moja droga kaszubska. cyt. wyd., s. 32; [bez autora]: Ruch młodokaszubski. cyt. wyd., s. 195.

119 J. Karnowski: Moja droga kaszubska. cyt. wyd., s. 34.

120 Janowicz [J. Karnowski]: Wcielenie idei młodo-kaszubskiej. „Gryf. Pismo dla spraw kaszubskich” 1909, nr 8, s. 229-331.

121 Tamże, s. 229-230.

122 [bez autora]: Ruch młodokaszubski. cyt. wyd., s. 192.

123 Janowicz [J. Karnowski]: Wcielenie idei młodo-kaszubskiej. cyt. wyd., s. 230.

124 Tamże, s. 230.

125 Tamże, s. 230. 
Przyjęcie perspektywy kultury jako polityki ujawnia, że kwestie tożsamościowe potrzebują dla swej legitymizacji „czystych” rozumień takich kategorii, jak język, kultura czy relacja jednej kultury do drugiej. Polityka - jako kontekst analizy - ujawnia także, że legitymizacja nie może opierać się na „życzeniach serca” - jak to ujął Karnowski ${ }^{126}$ - ale potrzebuje argumentów wyprowadzonych z nauki czy choćby tradycji. Dwukulturowość Kaszubów potrzebowała zatem „poważnej” w sensie jednoznacznej i racjonalnej legitymizacji politycznej, której podstawę stanowić mogła nauka albo „coś innego”. Wobec ekspansywnej polityki germanizacyjnej nie wystarczało bowiem, że wielu Kaszubów zwyczajnie „czuło się” Kaszubami-Polakami ${ }^{127}$. Podobnie był to niewystarczający argument w sytuacji zarzutów, czy nawet oskarżeń, o separatyzm ze strony osób i grup propolskich zarówno po stronie kaszubskiej, jak i polskiej.

Nie można zatem polityki sprowadzać wyłącznie do państwowości, gdyż polityczność konstruowana jest przez czynniki pozapaństwowe (czy też pozabiurokratyczne), jak prasa czy literatura, a nawet działania poszczególnych jednostek. Polityka i polityczność to zatem nie tyle kwestia państwa, ale nade wszystko kwestia narodu: ponieważ dotyka ona jego istotności. Idzie więc o religię, język, tradycję, ale także o ekonomię (w sensie gospodarowania) oraz o granice geograficzne i strategiczne. Najistotniejszą jednak kwestią jest język: to on jest największym skarbem narodu, jest jego główną zewnętrzną cechą, decyduje o spójności narodowej, a także sankcjonuje ducha narodu, w którym ten żyje $\mathrm{e}^{128}$.

\subsection{Pedagogiczność kultury w myśli młodokaszubskiej}

Jeśli przyjąć, że pedagogiczność podobnie jak polityczność jest tylko (albo: aż) wymiarem kulturowego bycia człowieka w świecie, to pedagogiczność trzeba też rozumieć jako edukacyjną przestrzeń jestestwa, o którym dzieje się namysł. Gdy myśl człowieka odnosi się do jego świata, wówczas nabiera znamion refleksyjności, a jej pedagogiczność pozwala poznawać i czynić świat w bezpośredniości jego doświadczania. Pedagogiczność Młodokaszubów to nie tylko metoda wcielenia w życie ideałów i dążeń, to przede wszystkim bu-

126 J. Karnowski: Moja droga kaszubska. cyt. wyd., s. 34.

127 Tamże, s. 23-24.

128 J. Chaciński: Z zagadnień polityki narodowej. „Prąd. Miesięcznik Społeczny i Literacko-Naukowy" 1910, R. 2, nr 6, s. 210-211. 
dzenie kaszubskości, a więc docieranie i otwieranie możliwości doświadczania sensu tego, co Karnowski nazwał "pierwiastkiem kaszubskim”.

Program Młodokaszubów wiązał się więc z budzeniem świadomości przy jednoczesnym uwrażliwianiu na kaszubskość, czyli na przyrodzone Kaszubom cechy rodzinne ${ }^{129}$, zatem na to, co „duszy kaszubskiej” drogie: ziemia, tradycja, mowa i wspólność narodowa i kulturowa z Polską ${ }^{130}$. Podstawę programu stanowiła antropologiczna koncepcja kultury ${ }^{131}$, co przekładało się na propagowanie poznawania kultury kaszubskiej za pośrednictwem poznawania człowieka i jego życia oraz materialnych reprezentacji tego życia ${ }^{132}$. Młodokaszubi odwoływali się do wspólnych doświadczeń związanych z tradycją i do wspólnotowych doświadczeń germanizacyjnych. Stąd też sprawa zachowania i rozwoju kultury stanowić miała dobro całej wspólnoty: inteligencji kaszubskiej i warstw niższych ${ }^{133}$. Sama zaś kultura definiowana była przez Młodokaszubów jako „wszystkie przejawy życia swojskiego objawiające się bądź to w podaniach, bajkach i pieśniach, bądź to w obyczajach, strojach, budowie chat i świątyń, które są fundamentem dla gmachu przyszłości, są tem czem ziemia rodzinna dla drzewa"134.

Namysł pedagogiczny Młodokaszubów konstruowany był wobec czterech podstawowych obszarów kulturowych: 1) zachowania odrębności kultury kaszubskiej (i języka), co przekładało się na konieczność budzenia świadomości jej potencjału ${ }^{135}$; 2) zachowania jedności kaszubskiej i polskiej w zakresie kultury i języka, to z kolei wiązało się z budzeniem świadomości znaczenia

129 [bez autora]: O czytelnię i zbiory ludoznawcze. „Gryf. Pismo dla spraw kaszubskich" 1910, nr 4-5, s. 97-98.

130 Janowicz [J. Karnowski]: Wcielenie idei młodo-kaszubskiej. cyt. wyd., s. 229-230 .

131 Koncepcja ta dobrze łączyła się z organicznym i funkcjonalnym myśleniem o kulturze.

132 Redakcja „GRYFA”: Nasz program. cyt. wyd., s. 1-5.

133 Redakcja „GRYFA”: U schytku roku. „Gryf. Pismo dla spraw kaszubskich” 1909, nr 9, s. 256-258; Janowicz [J. Karnowski]: Wcielenie idei mtodo-kaszubskiej. cyt. wyd., s. 229, 231; Ś. Sudomski [A. Majkowski]: O przyszłość ruchu młodokaszubskiego. cyt. wyd., s. 53-56.

134 Redakcja „GRYFA”: Nasz program. cyt. wyd., s. 5.

135 Tamże, s. 1-5; [bez autora]: Ruch młodokaszubski. cyt. wyd., s. 192; Janowicz [J. Karnowski]: Wcielenie idei młodo-kaszubskiej. cyt. wyd., s. 229-231; Ś. Sudomski [A. Majkowski]: Zjazd młodokaszubów. cyt. wyd., s. 180-181; tenże: Pole Gryfa. „Gryf. Pismo dla spraw kaszubskich" 1912, nr 9, s. 241-244. 
potencjału kultury kaszubskiej dla kultury polskiej i odwrotnie ${ }^{136}$; 3) budzenia "dumy szczepowej”, co w dużej mierze wiązało się z odbudowaniem poczucia wartości własnej kultury, a więc: z terapeutyczną odmianą działań edukacyjnych ${ }^{137}$; 4) budzenia odpowiedzialności za jakość życia teraźniejszego oraz przyszłego, to z kolei generować miało działania edukacyjne, które dziś nazwać by można świadomym obywatelstwem ${ }^{138}$.

Przywołane obszary programu edukacyjnego Młodokaszubów są jednocześnie przestrzeniami refleksji pedagogicznej, której osią jest ludzkie życie w konkretnej rzeczywistości historycznej i geograficznej. Jeśli bowiem wrócić do Herderowskiej filozofii kultury i języka, pamiętając także o myśli Kollára i Ceynowy, i za ich pośrednictwem przyjrzeć się programowi Młodokaszubów, to odnieść można wrażenie, że ten kulturowy bieg myśli znajduje swe upostaciowanie w programie młodokaszubskim, z którego można wyprowadzić konkretne cele edukacyjne w zakresie: wychowania, kształcenia i... terapii. Mamy tu więc do czynienia ze szczególnego rodzaju konwersją, w wyniku której kategorie filozoficzne (Herder), zostały spopularyzowane i przybrały ramy naukowego obrazu świata (Kollár) i uzyskały status nauki (językoznawstwa, etnografii, statystyki, polityki [ale w sensie nauki]: Kollár,

136 Redakcja „GRYFA”: Nasz program. cyt. wyd., s. 1; Ś. Sudomski [A. Majkowski]: Zjazd młodokaszubów. cyt. wyd., s. 195, s. 195-196; Redakcja "GRYFA”: U schytku roku. cyt. wyd., s. 256; Ks. W.: Gryf w Gdańsku. „Gryf. Pismo dla spraw kaszubskich” 1912, nr 1-2, s. 1-9; [bez autora]: Dive et impera. cyt. wyd., s. 33-41; [bez autora]: Kaszubi Zachodniopruscy w świetle statystki urzędowej pruskiej 1905 r. „Gryf. Pismo dla spraw kaszubskich" 1909, nr 2, s. 43; [bez autora]: Ruch młodokaszubski. cyt. wyd., s. 192-198; Ś. Sudomski [A. Majkowski]: Wybory do sejmu Rzeszy niemieckiej w roku 1912 na kaszubskim Pomorzu. „Gryf. Pismo dla spraw kaszubskich” 1912, nr 5, s. 117.

137 Redakcja "GRYFA”: Nasz program. cyt. wyd., s. 2; [bez autora]: Ruch mtodokaszubski. cyt. wyd., s. 192; Ś. Sudomski [A. Majkowski]: O przyszłość ruchu młodokaszubskiego. cyt. wyd., s. 54-55; Janowicz [J. Karnowski]: Wcielenie idei młodokaszubskiej. cyt. wyd., s. 229-231; [bez autora]: Kaszubi Zachodniopruscy w świetle statystki urzędowej pruskiej 1905 r. cyt. wyd., s. 34-35, 36, 39.

138 Redakcja „GRYFA”: U schytku roku. cyt. wyd., s. 256; Ks. W.: Gryf w Gdańsku. cyt. wyd., s. 1-9; [bez autora]: Dive et impera. cyt. wyd., s. 33-41; [bez autora]: Kaszubi Zachodniopruscy w świetle statystki urzędowej pruskiej 1905 r. cyt. wyd., s. 41-44; [bez autora]: Ruch mtodokaszubski. cyt. wyd., s. 192-198; Ś. Sudomski [A. Majkowski]: Wybory do sejmu Rzeszy niemieckiej w roku 1912 na kaszubskim Pomorzu. cyt. wyd., s. 113-117; [bez autora]: Zielony wywtaszczyciel. „Gryf. Pismo dla spraw kaszubskich” 1910, nr 6, ss. 161-168; [bez autora]: Zwycięstwo hakatyzmu nad nauka. cyt. wyd., s. 289-294. 
Ceynowa, Ramułt, Lorentz, Derdowski, Prajs, Brückner, Karnowski, Majkowski). Nauka ta miała dostarczyć wiedzy prawdziwej, bo usankcjonowanej metodą naukowego - czyli obiektywnego - badania świata, i jednocześnie została ona zredukowana do wiedzy pozytywnej, a więc takiej, która wskazywać będzie możliwą do osiągnięcia, waloryzowaną dodatnio zmianę. Kłopot Młodokaszubów wiązał się nie z kwestią politycznego wymiaru nauki, ale z kłopotliwością wieloznacznego nadmiaru jej rezultatów, wobec zakładanej przez nich jedności tego, co kaszubskie z tym, co polskie. Germanizacja - jako szczególnie niebezpieczna polityka kulturowa - wymusiła sytuację, w której jednocześnie odczuwana „sercem” przez Kaszubów kaszubskość i polskość potrzebowała jednoznacznej argumentacji dla politycznego przetrwania. Było to szczególne wyzwanie wobec braku jakiejkolwiek teoretycznej wiedzy (filozoficznej, naukowej czy politycznej) podejmującej problematykę tożsamości dwukulturowej i dwujęzykowej. W tej sytuacji argumentacji musiała dostarczyć konkretna wiedza językoznawcza, a jej prawdziwość (wobec istniejącej wielości, o czym pisałam wyżej) musiała być potwierdzona aktem politycznego wyboru, a nie metodami dociekań naukowych: nie szło tu więc o dochodzenie/dociekanie prawdy, ale o wybór prawy (Karnowski, Majkowski). W ten to sposób Młodokaszubi uzyskali dostęp do wiedzy unaukowionej, która równocześnie potwierdzała i opisywała teraźniejszy, przeszły i przyszły świat kulturowy. Znaczące dla wybranej wizji świata kwestie polityczne i pedagogiczne były sankcjonowane przy użyciu metod typowych dla logiki formalnej: „coś” było „na tak” lub było „na nie”; albo „coś” było "prawdą”, albo „fałszem”. W konsekwencji Młodokaszubi mogli zrekonstruować szeroki program edukacyjny, który gwarantowałby realizację zawartej w ich myśli (ideologii) wizji świata, gdyż ta wizja świata (ideologia) stanowiła „uzwyczajniony” cel działań edukacyjnych ${ }^{139}$.

\section{Zakończenie}

Wydaje się, że myśl młodokaszubska stanowi punkt węzłowy etnicznej biografii Kaszubów. Jest ona wyrazem kulturowego rozwoju idei regionalizmu kaszubskiego i potwierdza Herderowską tezę, że każde jestestwo posiada własny świat, i to wewnątrz tego świata wytworzony powinien być typowy dla niego wzorzec. W Herderowskim rozumieniu Młodokaszubi byliby za-

139 Kwestie ideologiczności i naukowości pedagogiki podejmuje Andrea Folkierska. A. Folkierska: Pytanie o pedagogikę. Warszawa 1990, UW. 
tem „ludźmi kultury” i sami chcieli, aby „Kaszubi byli ludźmi kultury”: w ich myśleniu świat jest kulturową ciągłością, a człowiek jest jej wytworem, ale i wytwórcą. Człowiek jest jestestwem wytwarzanym i tworzącym, a tym, co różni ludzi i wspólnoty, jest wyłącznie treściowy (jakościowy) wymiar ich dziejącego się świata-kultury. Młodokaszubi dostrzegli nie tylko polityczny aspekt kulturowego przetrwania, rozpoznali oni również, że kultura jest procesem, w którym splatają się wychowanie, kształcenie, terapia, antropologia, ekonomia, historia, tradycja itp. I choć w tekście skupiałam się na pedagogiczności i polityczności kultury, to często nie sposób w działaniu i myśleniu precyzyjnie rozerwać przywołanych aspektów, i orzec: to jest „pedagogiczne”, a to „polityczne”, a to znów „antropologiczne”. Istotne chyba jest to - co myśl młodokaszubska zdaje się potwierdzać - że świadomość istnienia wskazanych zakresów pozwala człowiekowi na (roz)budzenie świadomości posiadania własnej kultury, języka i świadomości bycia uczestnikiem i wytwórcą całości kultury, jako całości świata. Bo to przecież wychowanie - po Herderowsku - ma włączać człowieka w kulturową jedność świata, która powinna istnieć i tworzyć się na prawie wewnętrznie zróżnicowanej całości.

Myśl młodokaszubska jest węzłowa w tym sensie, że wraz z wyrażeniem aktu woli przynależności do państwa i narodu polskiego w pewien polityczny sposób domyka myślenie Ceynowy. I wraz z wypowiedzeniem politycznego aktu woli przynależności do państwa i narodu polskiego otwiera nowy rozdział myślenia o regionie w kooperacji z państwem, w taki sposób, by nie było to zagrażające dla kultury regionu i kultury państwa. Równocześnie ujawnia się tu myślenie o kulturze państwa: to, co ogólne (państwowe), tworzone jest z tego, co partykularne (swojskie/regionalne). Można by zatem przyjąć, że to nie „zasada krwi” (związki plemienno-szczepowe) buduje to, co ogólne, ale to „idea kultury” stanowi o jedności państwa. Gdyby uogólnić myślenie Młodokaszubów, można by przyjąć, że regionalizm - jako ruch myślowy i praktyczny - zawsze dzieje się w administracyjnym odrębnie państwa. Separatyzm zmierza do zmian administracyjnych. I regionalizm, i separatyzm dążą do dogłębnego i wnikliwego poznania regionu oraz państwa. Regionalizm jednak wykorzystuje uzyskaną wiedzę, by współtworzyć przy współodpowiedzialności regionu i państwa przestrzeń wspólnego życia teraźniejszego i przyszłego. I jednocześnie tak zagospodarowuje przeszłość, by to, co boleśnie rozłączne, stało się za pośrednictwem „terapeutycznej edukacji” nauką dla tego, co w teraźniejszości i przyszłości będzie krytycznie łączyć. Separatyzm potrzebuje wiedzy, by rozłączyć region i państwo, gdyż dostępna wie- 
dza dostarczać powinna argumentów dla przekonań, że wspólne życie teraźniejsze i przyszłe jest niemożliwe. Przeszłość dostarczać powinna bolesnych doświadczeń, które uzasadniać będą konieczność wytworzenia i utrzymania rozdzielności. Rany są zatem potrzebne, gdyż przypominać mają o krzywdzie historycznej, nie mogą więc zostać zabliźnione ani przez czas, ani za pomocą terapeutycznej edukacji.

Pozostając nadal w pewnym uogólnieniu myśli: edukacji regionalnej nie można zatem banalizować przez sprowadzanie jej wyłącznie do zajęć o wytworach ludowych danego regionu. Tak myślane i realizowane działanie nie jest edukacją regionalną w krytycznym tego słowa znaczeniu. Jak pokazuje ten tekst, regionalizm i edukacja regionalna są nierozerwalnie związane z pedagogicznością i politycznością kulturowego bycia człowieka w świecie. Nie można też edukacji regionalnej „uprawiać” w rozłączeniu z edukacją międzykulturową czy w rozerwaniu z namysłem nad kulturą jako równoprawną wielością. Polityczne uznanie faktu wielokulturowości - gdzie wszystkie kultury są sobie równe, a każda z nich wytwarza właściwy sobie wzorzec - zdaje się warunkiem koniecznym dla możliwości zaistnienia koncepcji regionalizmu i szeroko rozumianej (krytycznej) edukacji regionalnej.

I jednocześnie trzeba chyba pamiętać o tym, że separatyzm jest inną stroną tego, co zwykło się nazywać regionalizmem...

\section{Bibliografia}

[bez autora]: Jaka jest doktryna arystokracyi. „Demokrata Polski. Pismo polemiczne" 1838, t. 2 (od 7 listopada 1838 do 27 stycznia 1840 roku). [bez autora]: Niewolnictwo w Polsce. Licytacya na duszę Józefa Markowskiego. „Demokrata Polski. Pismo polemiczne” 1838, t. 2 (od 7 listopada 1838 do 27 stycznia 1840 roku).

[bez autora]: Nowe plany arystokracyi. „Demokrata Polski. Pismo polemiczne" 1838, t. 2 (od 7 listopada 1838 do 27 stycznia 1840 roku).

[bez autora]: Arystokracya i emancypacja ludu w Polsce. O emancypacji ludu w Polsce. „Demokrata Polski. Pismo polemiczne” 1840, t. 3 (od 14 lutego 1840 do 21 maja 1841 roku).

[bez autora]: Dive et impera. „Gryf. Pismo dla spraw kaszubskich” 1909, nr 2. [bez autora]: Kaszubi Zachodniopruscy w świetle statystki urzędowej pruskiej 1905 r. „Gryf. Pismo dla spraw kaszubskich” 1909, nr 2. 
[bez autora]: Odrodzenie Kaszub. „Gryf. Pismo dla spraw kaszubskich” 1909, nr 3.

[bez autora]: Ruch młodokaszubski. „Gryf. Pismo dla spraw kaszubskich” 1909, nr 7.

[bez autora]: O czytelnię i zbiory ludoznawcze. „Gryf. Pismo dla spraw kaszubskich" 1910, nr 4-5.

[bez autora]: Zielony wywłaszczyciel. „Gryf. Pismo dla spraw kaszubskich” 1910, nr 6.

[bez autora]: Zwycięstwo hakatyzmu nad nauka. „Gryf. Pismo dla spraw kaszubskich" 1910, nr 10.

Bauman Z.: Prawodawcy i ttumacze. Warszawa 1998, IFiS PAN.

Bénéton Ph.: Histoire de mots: culture as civilization. Paris 1975, Presses de la foundation nationale des sciences politiques.

Brückner A.: Dzieje języka polskiego. Lwów - Warszawa 1913, Towarzystwo Nauczycieli Szkół Wyższych we Lwowie, Składy Główne w Księgarniach: Gubrynowicza i Syna we Lwowie, Gebethnera J. Wolffa w Warszawie [Wydanie pierwsze: Lwów - Warszawa 1906 r.].

Cenôva F. dr. [F. Ceynowa]: Zvéczaje é wòbéczaje Kaszébskosłovjnskjèho narodé. „Skôrb Kaszébskosłovjnskjè mòvé”, Pjrszè xęgj pjrszi seszét. Svjecè 1866, Czôrnoxężnik J. Hauffe.

Cenôva F. dr., Wòjkasin ze Sławòszéna [F. Ceynowa]: Rozmòva Kaszèbé s Pòlôchę. „Skôrb Kaszébskosłovjnskjè mòvé”, Pjrszè xęgj drégj seszét. Svjecè 1868, Czôrnoxężnik J. Hauffe.

Černý J. M.: Slovanský sjezd v Praze roku 1848. Na památku čtyřicetiletou vypravuje a dokládá př́slušnými akty. Praha 1888, Nakladatel M. Knapp. Chaciński J.: Z zagadnień polityki narodowej. „Prąd. Miesięcznik Społeczny i Literacko Naukowy" 1910, R. 2, nr 6.

Derdowski H.J.: Ò panu Czôrlińsczim, co do Pùca pò sécë jachôł. Opr. J. Samp, J. Treder, E. Gołąbek. Gdańsk 2007, Wydawnictwo Instytutu Kaszubskiego.

Dupkala R.: „Filozofia humanitaryzmu” Herdera i jej oddźwięk na Stowacji w twórczości J. Kollara i P.J. Šafarika. W: M. Heinz, M. Potępa, Z. Zwoliński (red.): Rozum i świat. Herder i filozofia XVIII, XIX i XX wieku. Warszawa 2004, Wydawnictwo Genesais.

Folkierska A.: Pytanie o pedagogikę. Warszawa 1990, UW.

Herder J. G.: Dziennik z mojej podróży z roku 1769. Olsztyn 2002, Wydawnictwo Wspólnoty Kulturowej „Borussia”. 
Herder J. G.: Jeszcze jedna filozofia historii ksztattowania się ludzkości. W: T. Naumowicz (wybór i opr.): Państwo a społeczeństwo. Wizje wspólnot niemieckich od oświecenia do okresu restauracji. Poznań 2001, Wydawnictwo Poznańskie.

Herder J. G.: Narody stowiańskie W: J. G. Herder: Pomysty do filozofii dziejów rodzaju ludzkiego. T. 3. Wilno 1838, Nakład i druk: T. Glücksberga.

Herder J. G.: Pomysty do filozofii dziejów rodzaju ludzkiego. T. 1. Wilno 1838, Nakład i druk: T. Glücksberga.

Herder J. G.: Pomysty do filozofii dziejów rodzaju ludzkiego. T. 2. Wilno 1838, Nakład i druk: T. Glücksberga.

Herder J. G.: Rozprawa o pochodzeniu języka. W: J. G. Herder: Wybór pism. Wybór i opr. T. Namowicz. Wrocław - Warszawa - Kraków - Gdańsk Łódź 1987, Zakład Narodowy imienia Ossolińskich.

Herder J. G.: Wyjątki z listów o Osjanie i pieśniach dawnych ludów. W: J. G. Herder: Wybór pism. Wybór i opr. T. Namowicz. Wrocław - Warszawa - Kraków - Gdańsk - Łódź 1987, Zakład Narodowy Imienia Ossolińskich.

Hinrichs W.: Do realiów! Nowoczesne boje o „wyższe stanowisko”. Herder jako prekursor indywidualistycznej filozofii i pedagogiki, jak również filozofii i pedagogiki kultury. W: M. Heinz, M. Potępa, Z. Zwoliński (red.): Rozum i świat. Herder i filozofia XVIII, XIX i XX wieku. Warszawa 2004, Wydawnictwo Genesais.

Janowicz [J. Karnowski]: Nowe prądy na Kaszubach. „Prąd. Miesięcznik Społeczny i Literacko-Naukowy" 1910, R. 2, nr 6.

Janowicz [J. Karnowski]: Wcielenie idei młodo-kaszubskiej. „Gryf. Pismo dla spraw kaszubskich" 1909, nr 8.

Janowicz [J. Karnowski]: Zdania o stosunku językowym ludności kaszubskiej do polskiej. „Gryf. Pismo dla spraw kaszubskich” 1910, nr 4-5 (cz. 1).

Janowicz [J. Karnowski]: Zdania o stosunku językowym ludności kaszubskiej do polskiej. „Gryf. Pismo dla spraw kaszubskich” 1910, nr 7 (cz. 2).

Janowicz [J. Karnowski]: Zdania o stosunku językowym ludności kaszubskiej do polskiej. „Gryf. Pismo dla spraw kaszubskich” 1910, nr 9 (cz. 3).

Janowicz [J. Karnowski]: Zdania o stosunku ludności kaszubskiej do polskiej pod względem językowym. „Gryf. Pismo dla spraw kaszubskich” 1910, nr 12 (cz. 4).

Karnowski J.: Moja droga kaszubska. Gdańsk 1981, Wydawnictwo Zrzeszenie Kaszubsko-Pomorskie Oddział Miejski w Gdańsku. 
Kollár J.: O literackiej wzajemności między różnymi szczepami i narzeczami narodu słowiańskiego (Peszt 1837). W: J. Kollár: Wybór pism. Wrocław 1954, Zakład Narodowy im. Ossolińskich.

Ks. W.: Gryf w Gdańsku. „Gryf. Pismo dla spraw kaszubskich” 1912, nr 1-2. Labus T.: Recepcja pogladów Herdera w Europie Wschodniej i Potudniowo-Wschodniej. „Studia Filozoficzne” 1986, nr 7 (248).

Laclau E.: Emancypacje. Wrocław 2004, Wydawnictwo Naukowe Dolnośląskiej Szkoły Wyższej Edukacji TWP.

Lorentz F.: Obszar mowy kaszubskiej. „Gryf. Pismo dla spraw kaszubskich” 1909, nr 4.

Moraczewski J.: Opis pierwszego Zjazdu Stowiańskiego, Poznań 1848, Nakładem N. Kamieńskiego i Spółki.

Nitsch K.: Charakterystyka porównawcza dyalektów zachodnio-pruskich. „Rocznik Towarzystwa Naukowego w Toruniu” 1906, Tom XIII.

Nitsch K.: W sprawie pisowni kaszubskiej. „Gryf. Pismo dla spraw kaszubskich" 1910, nr 1.

P.W.: Smutnô prôwda. „Klëka” 1938, R. 2, nr 7.

Prajs P.I.: Rzecz o języku kaszubskim, W: Wojkasen [F. Ceynowa]: Kile słov wó Kaszebach e jich zemji. Tudzież rzecz o języku kaszubskim ze zdania sprawy Prajsa. Kraków 1850, Nakładem Księgarni i Czcionarni pod Sową.

Ramułt S.: Stownik języka pomorskiego czyli kaszubskiego. Kraków 1893, Wydawnictwo Akademia Umiejętności.

Ramułt S.: Statystyka ludności kaszubskiej. Kraków 1899, Wydawnictwo Akademii Umiejętności.

Redakcja „GRYFA”: Nasz program. „Gryf. Pismo dla spraw kaszubskich” 1908, nr 1.

Redakcja „GRYFA”: U schytku roku. „Gryf. Pismo dla spraw kaszubskich” 1909, nr 9.

Roppel L.: Dr Florian Ceynowa na miare stowiańską. Dwa listy Cenôvy do Ramutta. „Klëka” 1939, nr 3.

Stanisław [F. Ceynowa]: Wuvagi nad móva kaszebska, W: Stanisław [F. Ceynowa]: Trze rosprawe voros Wojkasen [F. Ceynowa]: Kile słov wó Kaszebach e jich zemji. Kraków 1850, Nakładem Księgarni i Czcionarni pod Sową.

Sudomski Ś. [A. Majkowski]: O przyszłość ruchu młodokaszubskiego. „Gryf. Pismo dla spraw kaszubskich" 1912, nr 3. 
Sudomski Ś. [A. Majkowski]: Pole Gryfa. „Gryf. Pismo dla spraw kaszubskich” 1912, nr 9.

Sudomski Ś. [A. Majkowski]: Wybory do sejmu Rzeszy niemieckiej w roku 1912 na kaszubskim Pomorzu. „Gryf. Pismo dla spraw kaszubskich” 1912, nr 5.

Sudomski S. [A. Majkowski]: Zjazd młodokaszubów. „Gryf. Pismo dla spraw kaszubskich" 1912, nr 7.

Ułaszyn H.: Dzieje języka polskiego Brücknera. „Rocznik Slawistyczny” 1908, t. 1.

Wójkasin [F. Ceynowa]: Kaszebji do Pólochov. „Szkoła Narodowa” 1850, nr 10.

\section{'Young Kashubians' - a cultural phenomenon. A contribution to reflection on regional education ${ }^{140}$}

\section{Summary}

What has been attempted in this study is recognizing what basically the cultural phenomenon of 'Young Kashubians' was and what its consequences were for shaping the Kashubian idea of regionalism and how it could enrich reflection on regional education in general. The authoress puts forward the thesis that the Young-Kashubian thought constitutes the key junction in the ethnic biography of Kashubians as it is a sign of the cultural development of the idea of Kashubian regionalism. This also confirms Herder's thesis that each being has its own world and it is inside this world where the typical model of this being should be created. Regionalism and education are inseparable from pedagogical and political character of man's cultural being in the world.

Key words: culture, regional culture, regional education, intercultural education 'Young Kashubians'

Translated by Agata Cienciała

140 The presented text is a draft fragment of the book: Fenomeny kultury kaszubskiej. Studium edukacji regionalnej /Phenomena of Kashubian Culture. A Study on Regional Education/(also a draft title). 